OPEN ACCESS

Edited by:

Gianluigi Giannelli,

National Institute of Gastroenterology

S. de Bellis Research Hospital (IRCCS), Italy

Reviewed by:

Arabella Young,

University of California, San Francisco,

United States

Paul Andrew Beavis,

Peter MacCallum Cancer

Centre, Australia

*Correspondence:

Jessica L. Bowser

jessica.l.bowser@uth.tmc.edu

†These authors have contributed equally to this work

Specialty section:

This article was submitted to Cancer Immunity and Immunotherapy,

a section of the journal

Frontiers in Immunology

Received: 30 November 2019

Accepted: 05 March 2020

Published: 15 April 2020

Citation:

Harvey JB, Phan LH, Villarreal OE and Bowser JL (2020) CD73's Potential as an Immunotherapy Target in

Gastrointestinal Cancers.

Front. Immunol. 11:508.

doi: 10.3389/fimmu.2020.00508

\section{CD73's Potential as an Immunotherapy Target in Gastrointestinal Cancers}

\author{
Jerry B. Harvey ${ }^{1 \dagger}$, Luan H. Phan ${ }^{1 \dagger}$, Oscar E. Villarreal ${ }^{2 \dagger}$ and Jessica L. Bowser ${ }^{1 *}$ \\ ${ }^{1}$ Department of Anesthesiology, The University of Texas Health Science Center at Houston, Houston, TX, United States, \\ ${ }^{2}$ Department of Gastrointestinal Medical Oncology, The University of Texas MD Anderson Cancer Center, Houston, TX, \\ United States
}

CD73, a cell surface 5'nucleotidase that generates adenosine, has emerged as an attractive therapeutic target for reprogramming cancer cells and the tumor microenvironment to dampen antitumor immune cell evasion. Decades of studies have paved the way for these findings, starting with the discovery of adenosine signaling, particularly adenosine A2A receptor (A2AR) signaling, as a potent suppressor of tissue-devastating immune cell responses, and evolving with studies focusing on CD73 in breast cancer, melanoma, and non-small cell lung cancer. Gastrointestinal (GI) cancers are a major cause of cancer-related deaths. Evidence is mounting that shows promise for improving patient outcomes through incorporation of immunomodulatory strategies as single agents or in combination with current treatment options. Recently, several immune checkpoint inhibitors received FDA approval for use in Gl cancers; however, clinical benefit is limited. Investigating molecular mechanisms promoting immunosuppression, such as CD73, in Gl cancers can aid in current efforts to extend the efficacy of immunotherapy to more patients. In this review, we discuss current clinical and basic research studies on CD73 in Gl cancers, including gastric, liver, pancreatic, and colorectal cancer, with special focus on the potential of CD73 as an immunotherapy target in these cancers. We also present a summary of current clinical studies targeting CD73 and/or $\mathrm{A} 2 \mathrm{AR}$ and combination of these therapies with immune checkpoint inhibitors.

Keywords: CD73, adenosine, gastrointestinal cancers, immunosuppression, immunotherapy

\section{INTRODUCTION}

Gastrointestinal (GI) cancers are some of the most common cancers worldwide and a major cause of cancer-related deaths (1-5). Immune checkpoint inhibitors (ICIs), including pembrolizumab (Keytruda) and nivolumab (Opdivo), antibodies against programmed death-1 (PD-1), recently gained Food and Drug Administration (FDA) approval for use in GI cancers (Table 1) (6-11). While their approval has been a significant step forward in advancing clinical care, currently, few patients benefit (12). Patients benefiting the most tend to have tumors harboring deficient DNA mismatch repair (dMMR) and high microsatellite instability $(\mathrm{MSI}-\mathrm{H})(8,13)$. dMMR and MSI-H occur together at a consistency of 90-95\% (referred to as dMMR/MSI-H) (14, 15). MMR deficiency leads to high mutational rates and subsequently high presence of neoantigens, making tumor cells more likely to be recognized and destroyed by antitumor immune cells $(8,13,16-$ 18). Tumor-infiltrating lymphocytes are abundant in dMMR/MSI-H tumors and associate with 
TABLE 1 | Summary of Food and Drug Administration approved immune checkpoint inhibitors in Gl cancers.

\begin{tabular}{|c|c|c|c|c|c|c|c|c|c|}
\hline Drug(s) & Target(s) & Therapy modality & Tumor type & Details & $\begin{array}{l}\text { Objective response rate } \\
\text { (\%) }\end{array}$ & $\begin{array}{l}\text { FDA approved } \\
\text { Year }\end{array}$ & Clinical trial & $\begin{array}{l}\text { ClinicalTrials.gov } \\
\text { identifier }\end{array}$ & $\begin{array}{l}\text { References } \\
\text { (PMID) }\end{array}$ \\
\hline \multirow[t]{3}{*}{$\begin{array}{l}\text { Pembrolizumab } \\
\text { (Keytruda) }\end{array}$} & PD-1 & $\begin{array}{l}\text { Humanized } \\
\text { monocolonal } \\
\text { antibody }\end{array}$ & Gastric Cancer & $\begin{array}{l}\text { Patients with recurrent locally } \\
\text { advanced or metastatic } \\
\text { gastric or gastroesophageal } \\
\text { junction adenocarcinoma } \\
\text { whose tumors express PD-L1 }\end{array}$ & $\begin{array}{l}60.0 \% \text { (combination with } \\
\text { cisplatin) } 25.8 \% \text { (single } \\
\text { agent) }\end{array}$ & 2017 & KEYNOTE-059 & NCT02335411 & 30911859 \\
\hline & & & Liver Cancer & $\begin{array}{l}\text { Patients with hepatocellular } \\
\text { carcinoma who previously } \\
\text { received sorafenib }\end{array}$ & $17 \%$ & 2018 & KEYNOTE-224 & NCT02702414 & 29875066 \\
\hline & & & $\begin{array}{l}\text { Colorectal } \\
\text { Cancer }\end{array}$ & $\begin{array}{l}\text { Patients with microsatellite } \\
\text { instability-high (MSI-H) or } \\
\text { deficient mismatch repair } \\
\text { (dMMR) unresectable or } \\
\text { metastatic colorectal cancer } \\
\text { that has progressed following } \\
\text { treatment with } \\
\text { fluoropyrimidine, oxaliplatin, } \\
\text { and irinotecan } \\
\text { Also approved for any solid } \\
\text { tumor that has tested positive } \\
\text { for MSI-H or dMMR in } \\
\text { patients who have had prior } \\
\text { treatment and have no } \\
\text { satisfactory alternative } \\
\text { treatment options }\end{array}$ & $\begin{array}{l}\text { Colorectal Cancer: } 40 \% \\
\text { (dMMR) 0\% (proficient MMR) } \\
\text { Non-colorectal Cancers: } \\
\text { 70\% (dMMR) }\end{array}$ & 2017 & KEYNOTE & NCT01876511 & 26028255 \\
\hline \multirow[t]{2}{*}{$\begin{array}{l}\text { Nivolumab } \\
\text { (Opdivo) }\end{array}$} & PD-1 & $\begin{array}{l}\text { Humanized } \\
\text { monocolonal } \\
\text { antibody }\end{array}$ & Liver Cancer & $\begin{array}{l}\text { Patients with advanced } \\
\text { hepatocellular carcinoma. The } \\
\text { approval covers the use of } \\
\text { nivolumab in patients who } \\
\text { have previously received } \\
\text { sorafenib }\end{array}$ & $15,20 \%$ & 2017 & $\begin{array}{l}\text { CheckMate } \\
040\end{array}$ & NCT01658878 & 28434648 \\
\hline & & & $\begin{array}{l}\text { Colorectal } \\
\text { Cancer }\end{array}$ & $\begin{array}{l}\text { Patients with MSI-H or dMMR } \\
\text { metastatic colorectal cancer } \\
\text { that has progressed following } \\
\text { treatment with } \\
\text { fluoropyrimidine, oxaliplatin, } \\
\text { and irinotecan }\end{array}$ & $68.9 \%$ & 2017 & $\begin{array}{l}\text { CheckMate } \\
142\end{array}$ & NCT02060188 & 28734759 \\
\hline $\begin{array}{l}\text { Nivolumab } \\
\text { (Opdivo) } \\
\text { Ipilimumab } \\
\text { (Yervoy) }\end{array}$ & $\begin{array}{l}\text { PD-1 } \\
\text { CTLA-4 }\end{array}$ & $\begin{array}{l}\text { Humanized } \\
\text { monocolonal } \\
\text { antibodies }\end{array}$ & $\begin{array}{l}\text { Colorectal } \\
\text { Cancer }\end{array}$ & $\begin{array}{l}\text { Patients with MSI-H or dMMR } \\
\text { metastatic colorectal cancer } \\
\text { that has progressed following } \\
\text { treatment with } \\
\text { fluoropyrimidine, oxaliplatin, } \\
\text { and irinotecan. }\end{array}$ & $55 \%$ & 2018 & $\begin{array}{l}\text { CheckMate } \\
142\end{array}$ & NCT02060188 & 29355075 \\
\hline
\end{tabular}


favorable prognosis $(19,20)$. For comparison, the somatic mutation frequency of $\mathrm{dMMR} / \mathrm{MSI}-\mathrm{H}$ tumors is $10-100$-fold to that of proficient MMR tumors (21). In contrast, ICIs as single agents have not shown meaningful benefit for proficient MMR tumors (8), which are the vast majority of GI cancer cases. MSI-H tumors account for $6-22 \%$ of gastric, $1 \%$ of pancreatic, $3 \%$ of liver, and $14-16 \%$ of colorectal cancers (2227). Antibodies against PD-1/programmed death-ligand 1 (PDL1) or cytotoxic T-lymphocyte-associated protein-4 (CTLA-4) are the most clinically advanced immunotherapy in cancer (12). The PD-1/PD-L1 axis promotes adaptive immune resistance by suppressing effector $\mathrm{T}$ cells and promoting the differentiation of regulatory T cells (Tregs). CTLA-4 also is a negative regulator of $\mathrm{T}$ cells; its engagement of B7-1 or B7-2 on antigen-presenting cells inhibits $\mathrm{T}$ cell activation (12). Preclinical and clinical efforts are pushing forward with combination ICI therapy as well as ushering in different approaches to harness the immune system to extend immunotherapy efficacy to more patients, including vaccines and viral therapy, adoptive cell transfer, and cytokine treatment $(12,28)$. Challenges with improving efficacy include overcoming immunosuppression activity by the tumor microenvironment, unmasking pre-existing immune cell activity, and the ability to stimulate de novo immunogenicity (29). In recent years, antibodies and small molecular inhibitors against CD73 have made their way into clinical trials as an attractive target for restoring antitumor immunity (30-44). This review provides a summary of current literature for CD73 in GI cancers and its potential as an immunotherapy target. We also discuss current clinical trials targeting CD73 and adenosine receptors in combination with ICI and conventional therapy and the clinical implications to GI tumors.

\section{CD73 AND ADENOSINE RECEPTOR ACTIVITY PROMOTES IMMUNOSUPPRESSION}

Ecto-5'nucleotidase (NT5E; CD73) serves as a pacemaker for generating extracellular adenosine. With tissue damage, inflammation, and hypoxic stress, ATP is released from stressed, necrotic, and/or apoptotic cells and is hydrolyzed stepwise by ectonucleoside triphosphate diphosphohydrolase1 (CD39), converting ATP to AMP, and CD73, converting AMP to extracellular adenosine (Figure 1). ATP's activation of ATP receptors promotes inflammation, whereas subsequent breakdown of ATP to extracellular adenosine and activation of adenosine receptors dampens inflammation (Figure 1) (4547). Extracellular adenosine signals though four adenosine receptors: A1R, A2AR, A2BR, and A3R (48). The earliest link of extracellular adenosine to immunosuppression include studies on the anti-inflammatory activity of methotrexate (49) and seminal studies revealing A2AR signaling as essential in suppressing tissue-devastating inflammation (50). Extracellular adenosine protects tissues by dampening inflammation with myocardial injury (51-53), acute lung injury (54-58), intestinal ischemia-reperfusion injury (59-61), and inflammatory bowel disease (62-65). Tumors exploit extracellular adenosine' to protect the cancer cells. Extracellular adenosine accumulates in tumors and suppresses cytotoxic $\mathrm{T}$ cells and natural killer cells (66-68). Multiple studies using syngeneic and/or spontaneous tumor models show tumor growth and metastasis is significantly reduced by genetic deletion or pharmacological blockade of CD73 or A2AR; this effect is largely due to restoring antitumor immunity (30-44, 67-70). These mice also benefit from increased chemotherapy sensitivity $(36,71)$ and reduced angiogenesis $(71$, 72). In line with these studies, many human tumors overexpress CD73 and associates with poor prognosis (36, 73-78). CD73 is also linked to drug resistance, epithelial-to-mesenchymal transition (EMT), and cancer cell proliferation and stemness (76, 79-84). Tumors also grow slower in A2BR-deficient mice and mice treated with $\mathrm{A} 2 \mathrm{BR}$ antagonists (85-87). For the most part, activation of $\mathrm{A} 2 \mathrm{AR}$ and to a lesser extent $\mathrm{A} 2 \mathrm{BR}$ on several types of immune cells, summarized below, promotes immunosuppression (Figure 1).

\section{Effector T Cells and T Regulatory Cells}

$\mathrm{A} 2 \mathrm{AR}$ is upregulated during inflammation on effector T cells. Its activation inhibits effector $\mathrm{T}$ cell proliferation, cytotoxic activity, and cytokine production [e.g., tumor necrosis factor- $\alpha$ (TNF$\alpha$ ), interferon-gamma (IFN- $\gamma$ ), interleukin-2 (IL-2)] (88-90). Whereas, A2AR activation on T regulatory (Treg) cells promotes Treg expansion and immunosuppressive activity [e.g., increasing forkhead box P3 (FoxP3) expression] (91). Mechanistically, these actions are linked together in a self-reinforcing loop. CD73 on Tregs generates extracellular adenosine and activates A2AR on effector T cells, suppressing effector T cell activity. Extracellular adenosine additionally activates A2AR on Tregs, promoting their expansion and activity (92). Human Tregs rarely express cell surface CD73 (93, 94), unlike mouse Tregs (92, 95). Instead, CD73 expression by surrounding cells or exosomes is considered to produce the extracellular adenosine. CD73 is expressed by populations of immune cells, stromal cells, epithelial and endothelial cells, cancer cells, and exosomes (96-98). Recently, CD39 co-expression with CD103 (integrin $\alpha$ E) was identified as a marker of antigen specific, tumor-reactive CD8 $+\mathrm{T}$ cells, having resident memory and a high capacity of recognizing and killing autologous tumor cells (99). These cells may be a strategy to improve adoptive cell therapy, which is limited by the ability to identify and expand tumor-reactive CD8 $+\mathrm{T}$ cells. Here, using CD39+ CD103+ to enrich the cells prior to in vitro expansion may increase therapy success (99). Many ongoing studies are directed at capturing and/or reinvigorating $\mathrm{T}$ cellmediated antitumor responses. These studies will provide greatly to new approaches for extending and improving immunotherapy efficacy in cancer. A2AR activity also promotes peripheral T cell tolerance, skewing $\mathrm{T}$ cell differentiation from adaptive effector cells to adaptive FoxP3 + lymphocyte activation gene-3 (LAG$3)+$ Tregs (100).

\section{Natural Killer Cells}

A2AR activation on natural killer (NK) cells inhibits NK cell maturation, proliferation, activation, production of cytotoxic cytokines (e.g., IFN- $\gamma$ and TNF- $\alpha$ ), and target cell killing $(38,101-107)$. Whereas, genetic deletion or pharmacological 


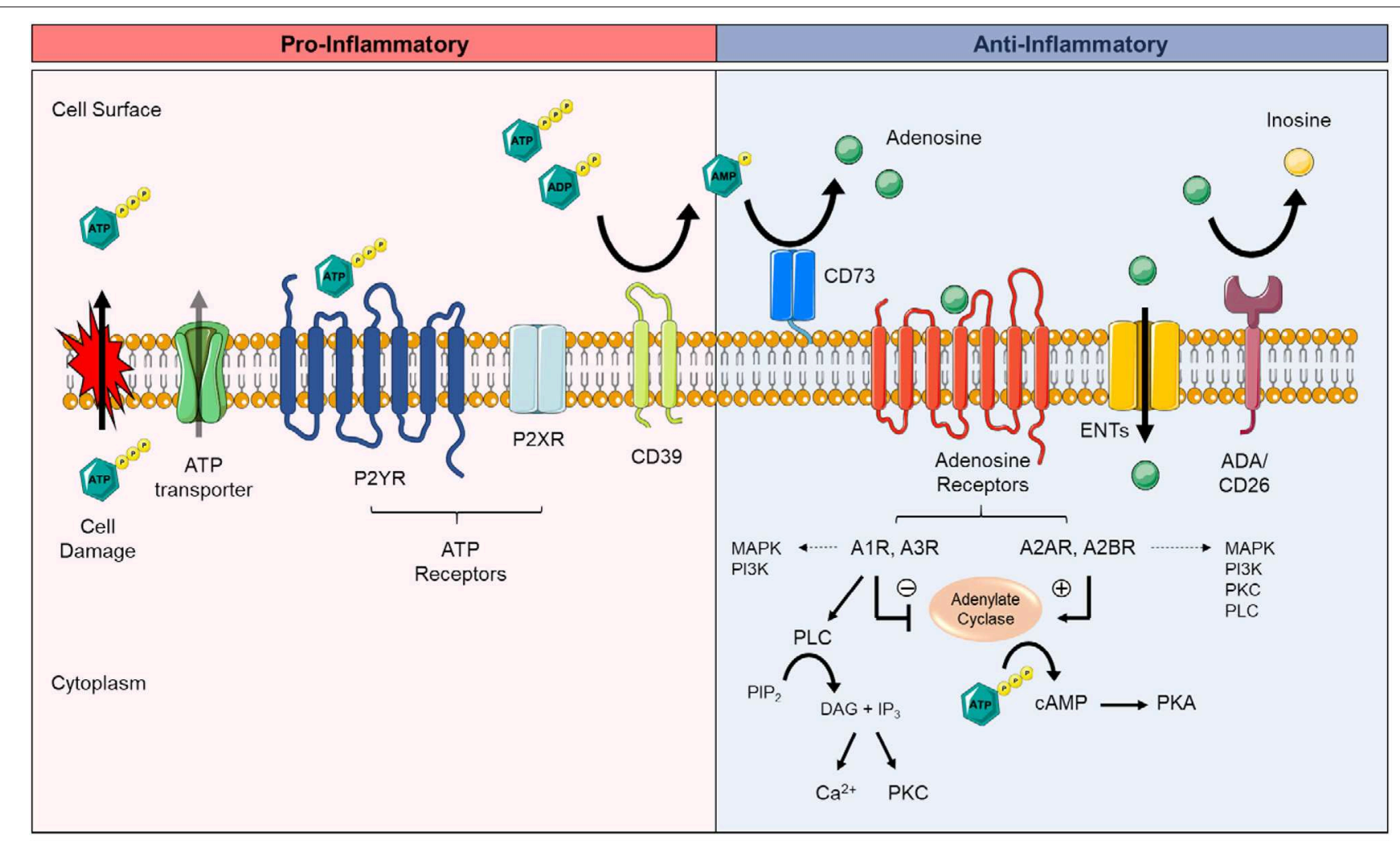

Tumor Immunosuppression

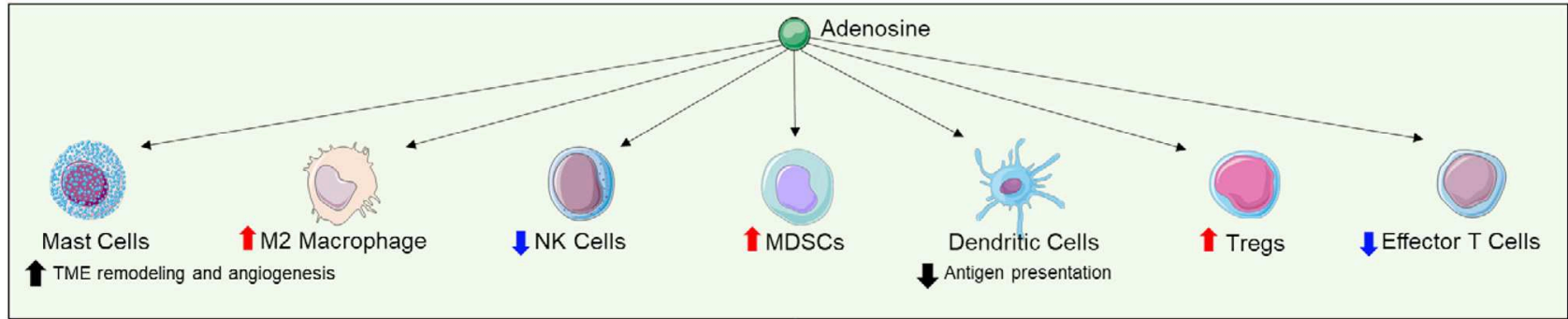

FIGURE 1 | Extracellular adenosine synthesis, adenosine receptor signaling, and adenosine-mediated immunosuppression. Extracellular adenosine and receptor signaling is part of a large cascade of ecto-enzymes (e.g., CD39, CD73), membrane transporters (e.g., ENTs), and G-protein-coupled (e.g., P2YR, adenosine receptors) and ionotrophic receptors (e.g., P2XR) known as the purinergic pathway. The purinergic pathway mediates both pro-inflammatory and anti-inflammatory responses. The breakdown of extracellular adenosine triphosphate (ATP) to extracellular adenosine is key to balancing tissue inflammation. Intracellular ATP is released by lytic (e.g., stressed and/or apoptotic/necrotic cells) and non-lytic (e.g., pannexin-1 and connexins) routes secondary to tissue damage, inflammation, and/or hypoxia. Once released, ATP activates ATP receptors (e.g., P2XR and P2YR) to promote pro-inflammatory responses, including the release of inflammatory cytokines promote lymphocyte proliferation, cell mobility, and phagocyte recruitment. ATP is dephosphorylated to extracellular adenosine by CD39, converting ATP and adenosine diphosphate (ADP) to adenosine monophosphate (AMP), and CD73, converting AMP to adenosine. Extracellular adenosine signaling through adenosine receptors (e.g., A1R, A2AR, A2BR, A3R) promotes anti-inflammatory responses, including the release of pro-tolerance cytokines, regulatory lymphocytes, and skewing toward M2 macrophages. Extracellular adenosine also can be taken up intracellularly by equilibrative nucleoside transporters (e.g., ENTs) or be further metabolized to inosine (e.g., ADA/CD26). A2AR and A2BR signaling stimulate adenylate cyclase to produce cyclic AMP (cAMP) which activates protein kinase A (PKA). A1R and A3R signaling inhibit adenylate cyclase. Adenosine receptors can activate multiple signaling pathways (e.g., MAPK, PI3K, PLC, PKC, ion channels), depending on cell and tissue types. Tumors exploit the anti-inflammatory actions of extracellular adenosine to evade antitumor immune cells. A3R activation on mast cells promotes tumor microenvironment (TME) remodeling and angiogenesis, increases the population of M2 macrophages, and promotes the accumulation of myeloid-derived suppressor cells (MDSCs) in tumors. A2AR activation on T regulatory cells (Tregs) enhances their immunosuppressive activity (e.g., suppressing effector T cells). A2AR and/or A2BR activation on natural killer (NK) cells, dendritic cells, and effector T cells dampens the antitumor activity of these cells. Abbreviations: ectonucleoside triphosphate diphosphohydrolase-1 (CD39), ecto-5' nucleotidase (CD73), adenosine deaminase (ADA), phospholipase C (PLC), protein kinase C (PKC), diacylglycerol (DAG), phosphatidylinositol 4,5-bisphosphate $\left(\mathrm{PIP}_{2}\right)$, inositol trisphosphate $\left(\mathrm{IP}_{3}\right)$, mitogen-activated protein kinase (MAPK), phosphoinositide 3-kinase (PI3K). 
blockade of $\mathrm{A} 2 \mathrm{AR}$ or respiratory hyperoxia restores $\mathrm{NK}$ cell maturation, proliferative capacity, and cytotoxic function, which improves control over tumor growth, delays tumor initiation and suppresses tumor metastasis $(38,101,102)$. CD73 and/or A2AR blockade or supplemental oxygen in combination with therapies promoting NK cell activity may be relevant strategies to enhance antitumor immunity. Whole-body exposure to $60 \%$ oxygen reduces tumor growth by reversing hypoxiaextracellular adenosine-mediated immunosuppression. In these preclinical studies, extracellular adenosine levels and CD39, CD73, A2AR, and A2BR gene expression decreases and coincides with increased antitumor immunity (102, 108). Hypoxiainducible factors (HIFs) are strongly linked to increasing CD73 (109), A2AR (110), and A2BR (111) gene expression and collaborates to increase extracellular adenosine/adenosine receptor signaling for dampening inflammation (46, 47). Interestingly, recent studies show tumor cells can reprogram NK cells to gain immunosuppressive functions [e.g., increase IL-10 and transforming growth factor- $\beta$ (TGF- $\beta$ ) production via signal transducer and activator of transcription 3 (STAT3) transcriptional activity, suppressing IFN- $\gamma$ production] (112). The effects are not mediated through adenosine receptors, suggesting other mechanisms are involved and may not involve the production of extracellular adenosine (112).

\section{Myeloid-Derived Suppressor Cells and Tumor-Associated Macrophages}

CD39 and CD73 are upregulated on CD11b + CD33+ peripheral blood and tumor-associated myeloid-derived suppressor cells (MDSCs) via TGF- $\beta$, which their ectonucleotidase activity inhibits $\mathrm{T}$ cell and NK cell activity (113). Granulocytic MDSCs expressing high CD39 and CD73 are described in colorectal cancer patients. These cells were found to exert robust immunosuppressive features (e.g., high PD-L1 expression) and activity that could be dampened by blocking CD39/CD73 (114). A2BR activation preferentially promotes the expansion and intratumoral accumulation of CD11b+ Gr1+ MDSCs (115). $\mathrm{CD} 11 \mathrm{~b}+\mathrm{Gr} 1+\mathrm{MDSCs}$ express high CD73, which limits $\mathrm{T}$ cell proliferation. CD73 is also considered to facilitate MDSC expansion by generating extracellular adenosine to activate A2BR on myeloid progenitors (115). Accordingly, blocking $\mathrm{A} 2 \mathrm{BR}$ reduces $\mathrm{CD} 11 \mathrm{~b}+\mathrm{Gr} 1+\mathrm{MDSCs}$ immunosuppression and accumulation in tumors (87). Extracellular adenosine generated by cancer cells can recruit tumor-associated macrophages (TAMs), which their endonucleotiase activity, in collaboration with CD73 expression on other cells of the tumor microenvironment, further contributes (e.g., suppressing antitumor $\mathrm{CD} 4+\mathrm{T}$ cell proliferation) to extracellular adenosine-mediated immunosuppression in tumors (116).

\section{Dendritic Cells}

Dendritic cells (DCs) transport tumor antigens to cytotoxic $\mathrm{T}$ lymphocytes for mounting antitumor immunity. A2BR activation on DCs inhibits their mobility, due to chemokine receptor downregulation, and they become tolerigenic to the tumor microenvironment (117-119). For instance, A2BR activation on DCs results in impaired allostimulatory activity and the expression of high levels of angiogenic, immunosuppressive, and tolerigenic factors [e.g., vascular endothelial growth factor (VEGF), IL-8, IL-6, IL-10, TGF- $\beta$, and idoleamine 2,3dioxygenase (IDO)] (118). These cells cannot prime CD8+ $\mathrm{T}$ cells and $\mathrm{T}$ helper type 1 (Th1) immune responses (118121). A2BR binding also inhibits monocyte differentiation to DCs $(118,119)$. A2BR blockade promotes DC activation (e.g., increased CD86 expression on CD11b- DCs), increases CD4+ and CD8 $+\mathrm{T}$ cell IFN- $\gamma$ production, and tumor cell IFN- $\gamma$ and CXCL10 expression (86), which supports the therapeutic potential of $\mathrm{A} 2 \mathrm{BR}$ antagonists in enhancing antitumor immunity. Pharmacological agents for blocking A2BR are in clinical trials (e.g., NCT03274479; see Clinical implications section).

\section{PRECLINICAL STUDIES TARGETING CD73 AND ADENOSINE RECEPTORS}

CD73's potential as an immunotherapy target has advanced rapidly within the last decade (30-44, 67-70). Current studies focus on combination strategies, including ICIs, adoptive transfer, chemotherapy, and targeted therapy. Preclinical studies show compelling evidence for both CD73 and A2AR blockade in enhancing anti-PD-1 and anti-CTLA-4 therapy. As single agents, both CD73 and A2AR blockade are effective in controlling tumor growth and metastasis. However, the combination of these therapies is far greater at reducing tumor growth, metastatic burden, and prolonging the life of mice. These effects depend on increased IFN- $\gamma$ production and CD8 $+\mathrm{T}$ and $\mathrm{NK}$ cell activity $(37,38,40,43,122,123)$. Notably, anti-PD-1 therapy is particularly synergized by inhibiting CD73, (37) and studies report A2AR combined with anti-PD-1 therapy is most effective with cancer cells expressing high CD73. The latter suggests CD73 expression may stratify patients likely to benefit from anti-PD-1 therapy-A2AR blockade combination (122, 123). In melanoma, CD73 is a poor pretreatment biomarker for immunotherapy, however, its expression level in relapse tumors has predictive value (41). Therefore, CD73 as a biomarker may be tumor and sample (e.g., primary, metastasis, relapse) specific. Ciforadenant (formerly, CPI-444), an oral A2AR antagonist, recently completed a first-in-human study in patients with renal cell cancer (124). Preclinical studies have shown ciforadenant combined with anti-PD-L1 or anti-CTLA-4 therapy eliminates tumors in up to $90 \%$ of mice, restores antitumor immunity, and is effective in mice that failed prior anti-PD-L1 or antiCTLA-4 therapy (68). Moreover, ciforadenant produced an antitumor memory response in which tumor growth was completely inhibited in mice with cleared tumors when later rechallenged (68). In clinical trials, cirforadenant combined with atezolizumab (anti-PD-L1 therapy) provide great disease control and survival benefit in patients, yet without high objective response rates (124). While reasons are unclear, the Fong and colleagues predict the response is due to persistent antitumor immunity that maintains durable control over tumor growth (124). Monotherapy ciforadenant also provided disease control in some individuals (124). Mechanistically, ciforadenant suppresses the expression of multiple checkpoint pathways on 
CD8+ effector T cells and CD4+ FoxP3+ Tregs and appears to have profound effects in restoring antitumor immunity at the draining lymph nodes by decreasing PD-1 and LAG-3 expression (69). Thus, a significant benefit of A2AR antagonism is its expansion of responsive cytotoxic T lymphocytes (69). A2AR and/or CD73 blockade also improves anti-CTLA-4 therapy efficacy in melanoma (43). Recently, anti-CD73 therapy combined with an agonist antibody to $4-1 \mathrm{BB}$ (4-1BB therapy) showed to restore antitumor immunity (125). 4-1BB is an activation-induced $\mathrm{T}$ cell costimulatory molecule that enhances cytotoxic T cell and NK cell activity $(126,127)$. 4-1BB therapy has entered into clinical trials involving GI cancer patients (NCT03330561). Poor efficacy and toxicity have been a concern in the past with 4-1BB therapy (128). Further preclinical studies are warranted.

Cancer vaccines educate the immune system to recognize cancer cells. Targeting A2AR in this setting also represents a promising strategy. Responses to melanoma and lymphoma tumor vaccines are increased in A2AR-deficient mice; these mice showed increased expansion of tumor-specific CD8+ $\mathrm{T}$ cells and increased survival compared to wild-type mice (129). The effectiveness of adoptive $\mathrm{T}$ cell transfer is also increased with genetic deletion or blockade of CD73 or A2AR. Tumorbearing mice benefit from improved tumor control and survival due to increased infiltration and activation of adoptive $\mathrm{T}$ cells $(30,69,70)$.

Additionally, preclinical studies show chimeric antigen receptor $\mathrm{T}(\mathrm{CAR} \mathrm{T})$ cell efficacy is greatly increased by $\mathrm{A} 2 \mathrm{AR}$ antagonism (130). CAR activation increases A2AR expression and suppression of mouse and human CAR T cells, which can be reversed by $\mathrm{A} 2 \mathrm{AR}$ antagonism or genetic targeting, increasing the therapy benefit of CAR T cells. Efficacy is increased further by combination therapy (A2AR blockade and anti-PD-1 therapy) (130). Increased CD73 expression is seen in patients progressing under adoptive $\mathrm{T}$ cell transfer therapy (41). Accordingly, future approaches targeting CD73 in combination with A2AR blockade, anti-PD-1 therapy, and/or adoptive $\mathrm{T}$ cell transfer may prove beneficial. Head-to-head comparison studies blocking CD39 and CD73 (44) or CD73 and A2AR (39) also show promise for significantly increasing antitumor immunity. Co-targeting CD73 with A2AR inhibits the compensatory response of A2AR blockade to increase CD73 (39). Whereas, co-targeting CD39 with CD73 is beneficial by targeting two different mechanisms (44). Blocking CD39 elevates ATP levels. High ATP levels promote DC and macrophage antitumor activity, which adds to the antitumor immunity benefits of blocking CD73 (44). Combining CD73 anti-antibodies or small molecule inhibitors with chemotherapy or targeted therapies [e.g., antibodies against epidermal growth factor receptor (EGFR)] also shows merit in preclinical studies $(36,81)$. BRAF and MEK inhibitors combined with A2AR blockade show significant benefit in controlling melanoma tumor growth and metastasis in mice (42). A benefit of BRAF and MEK inhibitor combination is that it downregulates CD73 expression (42). Accordingly, this combination strategy provides the advantage of dampening CD73 expression without added drug/antibody therapy. Preclinical studies that focus on GI cancers will be essential in understanding the therapeutic potential of CD73 and/or adenosine receptor blockade in these tumors.

\section{GASTRIC CANCER}

Gastric cancer (GC) is the fifth and third most common cancer and cause of cancer deaths worldwide, respectively (1). Although incidence and death rates are declining (131), advancements in prevention and treatment remain a priority. Five year survival rates drop to $20-30 \%$ or less once the cancer moves beyond the lining of the stomach (132). The majority of GC cases are advanced stage (133). Treatment includes gastric resection, radiation, chemotherapy, and targeted therapy, including antibodies against (VEGF)/VEGF receptor 2 (VEGFR2), and HER2 (131). Recently, ICI therapy was approved for GC (Table 1) (6). However, most patients do not benefit. Other immunotherapies being studied in GC include combination ICI therapy, adoptive cell transfer, vaccines [e.g., melanoma-associated antigen (MAGE) A3 peptides; Bacillus Calmette-Guerin (BCG)], and agonist antibodies for costimulatory receptors [e.g., OX40 (also known as tumor necrosis factor receptor superfamily, member 4), 4-1BB] (134).

Few studies have assessed CD73 expression in GC (Table 2). CD73 expression is higher in GC vs. normal tissue and associates with poor tumor differentiation, increased depth of invasion, positive nodal status, presence of metastasis, advanced-stage disease, and poor overall survival (Table 2) $(75,135)$. Increased CD73 in GC may be due in part to hypoxia. Hypoxia-inducible factor-1 $\alpha$ (HIF-1 $\alpha)$ staining closely correlates with high CD73 expression in gastric tumors (75). In contrast, gene expression studies have shown high CD73 expression associates with favorable overall survival in GC (136). Notably, CD73 expression does not always correlate to protein expression, which may explain the differences between these studies (136). Additionally, significant heterogeneity for CD73 is seen in GC $(75,135)$. For example, $30-50 \%$ of advanced stage, deeply invasive, and lymph node-positive tumors express low or no CD73 (75). Significant heterogeneity for CD73 expression is also described for melanoma $(41,42)$. In melanoma, CD73 expression is influenced by sample type (e.g., primary, metastatic, or relapse tissue); therapy treatment; and presence of activating MAPK (e.g., BRAF) mutations, mitogenic and inflammatory signals [e.g., hepatocyte growth factor (HGF) and TNF- $\alpha$ ], and necrosis $(41,42)$. Increased $C D 73$ expression with $B R A F$ mutation is also seen in serous ovarian cancer; these patients have better clinical outcomes (137). BRAF mutations are found in 10-20\% of colorectal cancer and frequently are MSI-H (138-140). CD73 expression is also impacted by NT5E promoter methylation, described for both melanoma and breast cancer $(141,142)$. Suffice to say, multiple molecular and genetic factors can affect CD73 expression in human tumors.

Looking ahead, assessing CD73 expression to common molecular and/or genetic alterations of GC and The Cancer Genome Atlas (TCGA) may help to better understand CD73 in GC (23). Studies assessing the association of CD73 expression to immune checkpoints, such as PD-L1, may also 
TABLE 2 | Summary of studies assessing CD73 expression in human Gl cancers,

\begin{tabular}{|c|c|c|c|c|c|c|c|}
\hline Tumor type & Study & Findings & \# of patients & Test method(s) & $\begin{array}{l}\text { CD73 high advance } \\
\text { stage tumors }\end{array}$ & $\begin{array}{l}\text { Clinical } \\
\text { significance }\end{array}$ & $\begin{array}{l}\text { Reference } \\
\text { (PMID) }\end{array}$ \\
\hline \multirow[t]{3}{*}{ Gastric Cancer } & Lu et al. & $\begin{array}{l}\text { CD73 expression is higher in gastric cancer vs. normal tissue; } \\
\text { High CD73 expression is positively correlated with tumor } \\
\text { differentiation, histology, depth of invasion, nodal status, } \\
\text { metastasis, American Join Committee on Cancer (AJCC) stage, } \\
\text { and poor survival }\end{array}$ & 68 & $\mathbb{H C}$ & $50 \%$ & Poor prognosis & 23569336 \\
\hline & Jiang et al. & $\begin{array}{l}\text { High CD73 expression associates with favorable overall survival } \\
\text { in gastric cancer; } \\
\text { Meta-analysis study reports large heterogeneity for high CD73 } \\
\text { expression for tumors (tumors: ovarian, breast, colorectal, } \\
\text { gastric, gallbladder, prostate, rectal, renal, bladder, head and } \\
\text { neck cancer, and NSCLC) }\end{array}$ & Oncomine database & $\begin{array}{l}\text { mRNA, IHC } \\
\text { (meta-analysis) }\end{array}$ & - & Better overall survival & 29514610 \\
\hline & Hu et al. & $\begin{array}{l}\text { CD73 expression is higher in gastric cancer vs. normal; } \\
\text { High CD73 associates with advanced clinical stage, deep } \\
\text { tumor invasion, lymph node metastasis, distant metastasis, and } \\
\text { poor survival }\end{array}$ & $\begin{array}{l}408 \text { (gastric cancer; } \\
\text { TCGA) } \\
131 \text { (gastric cancer; } \\
\text { FFPE) }\end{array}$ & $\begin{array}{l}\text { mRNA (TCGA), IHC, } \\
\text { Western Blot }\end{array}$ & $69 \%$ & Poor prognosis & 30992388 \\
\hline \multirow[t]{5}{*}{ Liver Cancer } & Shrestha et al. & $\begin{array}{l}\text { CD73 associates with poor overall survival and recurrence-free } \\
\text { survival; } \\
\text { Patients with tumors expressing high PD-L1 and high CD73 } \\
\text { have poor prognosis }\end{array}$ & $\begin{array}{l}\text { 1,170 (combined } \\
\text { datasets; GSE10143; } \\
\text { GSE10186; } \\
\text { GSE17856; TGCA } \\
\text { Liver Cancer) }\end{array}$ & mRNA & - & $\begin{array}{l}\text { Poor prognosis; } \\
\text { Poor recurrence free } \\
\text { survival in patients } \\
\text { with high PD-L1 }\end{array}$ & 30057891 \\
\hline & Shali et al. & $\begin{array}{l}\text { CD73 expression is higher in tumor vs. normal tissue; } \\
\text { CD73 expression is positively correlated with epidermal growth } \\
\text { factor receptor (EGFR) expression }\end{array}$ & 30 & $\mathrm{IHC}$ & - & - & 30417547 \\
\hline & Ma et al. & $\begin{array}{l}\text { CD73 expression is higher in hepatocellular carcinoma (HCC) } \\
\text { vs. normal tissue; } \\
\text { High CD73 expression correlates with microvascular invasion, } \\
\text { poor differentiation increased time to recurrence, shorter overall } \\
\text { survival, increased circulating tumor cells, and to } \\
\text { epithelial-to-mesenchymal transition in HCC }\end{array}$ & $\begin{array}{l}232 \text { (mixed: primary } \\
\text { tumors, recurrence } \\
\text { lesions, and } \\
\text { metastases) }\end{array}$ & $\begin{array}{l}\text { mRNA, IHC, Western } \\
\text { Blot }\end{array}$ & $57 \%$ & Poor prognosis & 30971294 \\
\hline & Sciarra et al. & $\begin{array}{l}\text { Immunohistochemistry study of CD73 expression in normal and } \\
\text { hepatobiliopancreatic tissues; } \\
\text { CD73 expression is present in all HCC, staining for CD73 } \\
\text { ranges from intensity of } 1+\text { to } 3+\text { with a median intensity of } 2+\text {; } \\
\text { Aberrant membranous and/or high/strong cytoplasmic } \\
\text { expression for CD73 is seen in invasive HCC }\end{array}$ & 24 & $\mathbb{H C}$ & $\begin{array}{l}\text { CD73+ Staining } \\
\text { Intensity = 3: } 63 \%\end{array}$ & - & 30607549 \\
\hline & Snider et al. & $\begin{array}{l}\text { NT5E is regulated by alternative splicing, producing a second } \\
\text { transcript, NT5E-2 in liver cirrhosis and HCC; } \\
\text { NT5E-2 is specific to humans and produces a protein product } \\
\text { known as CD73 short (CD73s) that lacks enzyme activity (lacks } \\
\text { exon 7) and is localized to the cytoplasm; } \\
\text { NT5E-2 is expressed at baseline in many normal human tissues; } \\
\text { CD73s expression is 6-8-fold higher in HCC compared to } \\
\text { normal liver tissues, whereas CD73 (NT5E) mRNA is } \\
\text { dramatically deceased (>90\%) in HCC }\end{array}$ & $\begin{array}{l}6 \text { (HCC) } \\
4 \text { (Cirrhosis) } 2 \\
\text { (Normal Liver) }\end{array}$ & $\begin{array}{l}\text { mRNA, } \\
\text { Immunofluorescence, } \\
\text { Western Blot, Enzyme } \\
\text { Activity }\end{array}$ & $\begin{array}{l}\text { mRNA Expression HCC: } \\
\text { NT5E-2 = 6-8-fold } \\
\text { increase; } \\
\text { NT5E }=90 \% \text { decrease }\end{array}$ & $\begin{array}{l}\text { Human specific } \\
\text { isoform for CD73, } \\
\text { NT5E-2 (CD73s) that } \\
\text { lacks enzyme activity } \\
\text { CD73s increases in } \\
\text { HCC, whereas CD73 } \\
\text { decreases in HCC. } \\
\text { CD73s is restricted to } \\
\text { the cytoplasm }\end{array}$ & 25298403 \\
\hline
\end{tabular}


TABLE 2 | Continued

\begin{tabular}{|c|c|c|c|c|c|c|c|}
\hline Tumor type & Study & Findings & \# of patients & Test method(s) & $\begin{array}{l}\text { CD73 high advance } \\
\text { stage tumors }\end{array}$ & $\begin{array}{l}\text { Clinical } \\
\text { significance }\end{array}$ & $\begin{array}{l}\text { Reference } \\
\text { (PMID) }\end{array}$ \\
\hline & Alcedo et al. & $\begin{array}{l}\mathrm{CD} 73 \text { exhibits aberrant N-linked glycosylation in HCC cells and } \\
\text { is independent of HCC etiology, tumor stage, or fibrosis } \\
\text { presence. Aberrant glycosylation of CD73 results in a 3-fold } \\
\text { decrease in enzyme activity; } \\
\text { CD73 does not correlate with tumor immune subtype in HCC }\end{array}$ & $\begin{array}{l}\text { HCC samples from } \\
\text { PanCancer Atlas } \\
\text { Consortium (mRNA) } \\
\text { and } 33 \text { HCC (all other } \\
\text { assays) }\end{array}$ & $\begin{array}{l}\text { mRNA, } \\
\text { Immunofluorescence, } \\
\text { Western Blot, Enzyme } \\
\text { Activity, Mass } \\
\text { Spectrometry }\end{array}$ & $\begin{array}{l}\text { CD73 Enzyme Activity: } \\
\text { aberrant glycosylation of } \\
\text { CD73 = 3-fold decrease } \\
\text { in enzyme activity }\end{array}$ & $\begin{array}{l}\text { CD73 is aberrantly } \\
\text { glycosylated which } \\
\text { significantly } \\
\text { decreases its enzyme } \\
\text { activity }\end{array}$ & 31592495 \\
\hline \multirow[t]{3}{*}{ Pancreatic Cancer } & Zhou et al. & $\begin{array}{l}\text { CD73 expression is higher in pancreatic ductal } \\
\text { adenocarcinoma (PDAC) vs. normal tissues; } \\
\text { High CD73 expression associates with increased tumor size, } \\
\text { tumor stage, TMN stage, and poor prognosis }\end{array}$ & 114 & mRNA, IHC & 40\% (TMN stage) & Poor prognosis & 30927045 \\
\hline & Sciarra et al. & $\begin{array}{l}\text { Immunohistochemistry study of CD73 expression in normal and } \\
\text { hepatobiliopancreatic tissues; } \\
\text { CD73 is negative in acinar and islet epithelial cells, variable in } \\
\text { pancreatic ducts, and mildly localized to stromal cells of normal } \\
\text { and inflamed tissues; } \\
\text { CD73 is expressed in 100\% of PDAC; } \\
\text { CD73 is expressed in a subset of pancreatic neuroendocrine } \\
\text { neoplasms (PanNET/PanNEC) and almost absent in acinar cell } \\
\text { carcinoma; } \\
\text { Different staining patterns for CD73 are observed in PDAC, } \\
\text { well- and moderately-differentiated tumors (grade } 1 \text { and grade } \\
\text { 2) express apical CD73 staining similar to pancreatic ducts or } \\
\text { express mixed membrane and cytoplasm staining; } \\
\text { Poorly-differentiated PDACs express aberrant CD73 staining; } \\
\text { PDAC, pancreatic ductal adenocarcinoma; MCA, mucinous } \\
\text { cystadenoma; IPMN, intraductal papillary mucinous neoplasm; } \\
\text { PanNET/PanNEC, pancreatic neuroendocrine tumor/pancreatic } \\
\text { neuroendocrine carcinoma; ACC, acinar cell carcinoma }\end{array}$ & $\begin{array}{l}42 \text { (PDAC) } 5 \text { (MCA) } \\
13 \text { (IPMN) } \\
23 \text { (PanNET/PanNEC) } \\
19 \text { (ACC) }\end{array}$ & IHC & $\begin{array}{l}\text { CD73+ Staining } \\
\text { Intensity = 3: 62\% } \\
\text { (PDAC) 0\% (MCA) 0\% } \\
\text { (IPMN) 4\% } \\
\text { (PanNET/PanNEC) 5\% } \\
\text { (ACC) }\end{array}$ & $\begin{array}{l}\text { PDAC: poor tumor } \\
\text { differentiation and } \\
\text { poor overall survival }\end{array}$ & 30607549 \\
\hline & Katsuta et al. & $\begin{array}{l}\text { PanNET/PanNEC express mild to moderate CD73 and } \\
\text { associates with invasion into adjacent organs }\end{array}$ & 44 & $\mathrm{IHC}$ & $54 \%$ & $\begin{array}{l}\text { Invasion into adjacent } \\
\text { organ }\end{array}$ & 26691441 \\
\hline \multirow[t]{2}{*}{ Colorectal Cancer } & Wu et al. & $\begin{array}{l}\text { CD73 expression is higher in colorectal cancer (CRC) vs. } \\
\text { normal tissue; } \\
\text { High CD73 expression associates with poor tumor } \\
\text { differentiation, advanced tumor stage, metastasis, and poor } \\
\text { overall survival }\end{array}$ & $\begin{array}{l}223 \text { (cohort 1) } \\
135 \text { (cohort 2) }\end{array}$ & IHC, Western Blot & - & Poor prognosis & 22287455 \\
\hline & Zhang et al. & $\begin{array}{l}\text { CD73 expression in rectal cancer only samples; } \\
\text { CD73 expression is increased in both tumor and stromal cells; } \\
\text { High CD73 expression in cancer cells associates with poor } \\
\text { patient prognosis; } \\
\text { High CD73 expression in stromal cells associates with favorable } \\
\text { characteristics (early T and tumor-node-metastasis (TMN) } \\
\text { stages) and overall survival; } \\
\text { Patients with high CD73 expression in both the cancer cells } \\
\text { and stromal cells have similar good outcomes. No CD73 } \\
\text { expression in both cell compartments is also favorable }\end{array}$ & 90 & $\mathrm{IHC}$ & - & $\begin{array}{l}\text { High CD73 } \\
\text { expression cancer } \\
\text { cells = poor } \\
\text { prognosis; } \\
\text { High CD73 } \\
\text { expression stromal } \\
\text { cells = favorable } \\
\text { outcomes }\end{array}$ & 25677906 \\
\hline
\end{tabular}




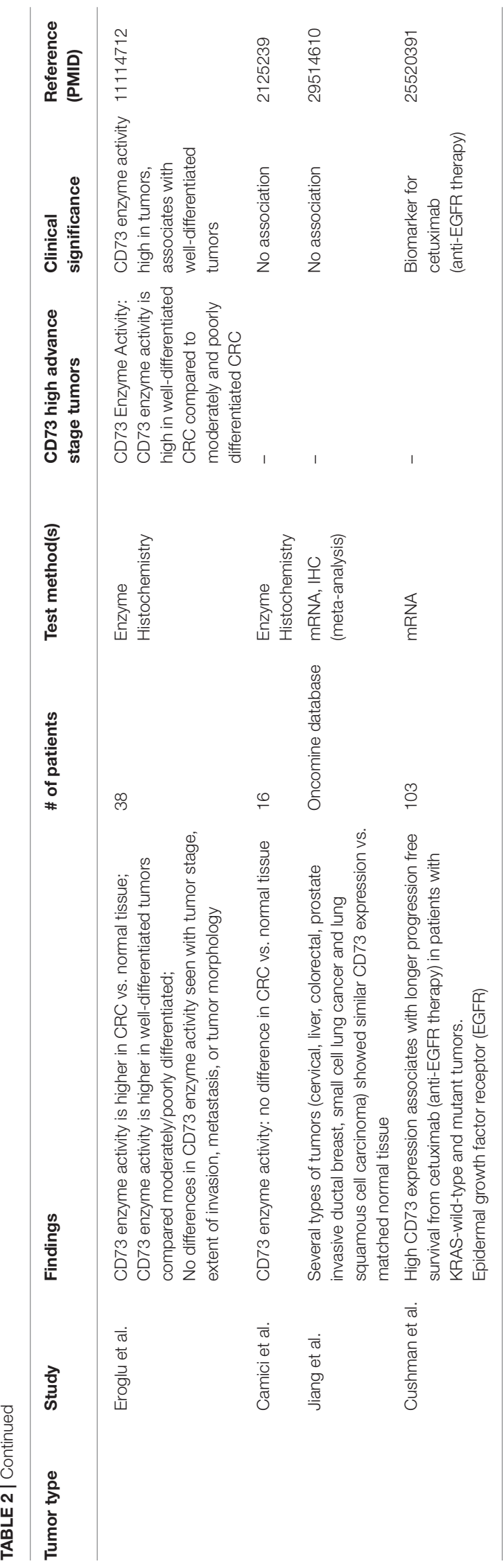

be helpful. Forty percent of GC cases are PD-L1 positive (143), and preclinical studies suggest high CD73 expression in $\mathrm{PD}-1 / \mathrm{PD}-\mathrm{L} 1$ expressing tumors may identify patients that would benefit from combination anti-PD-1/PD-L1 therapy and CD73 and/or A2AR blockade $(122,123)$. Few studies globally assess CD73 expression with other ecto-enzymes involved in ATP and adenosine synthesis and metabolism and its intracellular uptake (144), such as other E-NTPDases, ectonucleotide pyrophosphatases/phosphodiesterases (e.g., CD203a), nitcotinamide dinucleotide enzyme (e.g., CD38), prostatic acid phosphatase, alkaline phosphatase (45, 145, 146), adenosine deaminase, and equilibrative and concentrative nucleoside transporters (ENTs and CNTs, respectively). Reviewed recently by Boison and Yegutkin (144), this may present a major gap in developing effective adenosine-based therapies (144). Accordingly, a more global view of extracellular adenosine metabolism and signaling in GC may also prove significant.

Considering CD73/extracellular adenosine's role in immune cell escape, studies of CD73's association to $H$. pylori-mediated tumorigenesis may provide additional insight. $H$. pylori infection is responsible for up to $60 \%$ of GC cases and arises in the background of inflammation $(147,148)$. Immune cell evasion is important for $H$. pylori infection and supported by evidence of higher PD-L1 expression in $H$. pylori positive compared to negative gastric biopsies (149) and that $H$. pylori-induced PD-L1 expression on gastric epithelial cells converts naïve $\mathrm{T}$ cells to CD4+ FoxP3 + Tregs that inhibit $\mathrm{T}$ cell proliferation (150). CD73 expression by CD4+ CD25+ Tregs enhances $H$. pylori infection by increasing local extracellular adenosine, which suppresses IFN- $\gamma$ production (151). Consistent with this, infected CD73-deficient mice experience worse gastritis and more severe inflammation (e.g., increased IL-2, TNF- $\alpha$, and IFN- $\gamma$ and impaired Treg function) (151). Taken together, these studies support that CD73/extracellular adenosine in collaboration with other immune checkpoints may downregulate immune cell responses necessary for recognizing and clearing transformed cells arising in chronically infected gastric tissues, thus supporting GC development. With H. pylori infection, CagA and VacA containing exosomes are released from gastric epithelial cells, stimulating pro-inflammatory responses and affecting the expression of tumor suppressor and oncogenic genes (152). Considering CD73 expression on exosomes promotes tumor immunosuppression $(97,98)$, it would be interesting to see if CD73 is also expressed on $H$. pylori-mediated exosomes and if its presence or increased presence is a biomarker for the onset of GC.

Additional studies show CD73 promotes tumor cell proliferation, migration, invasion, and stemness in GC cells $(135,153)$. Antitumor roles for extracellular adenosine are also reported, including AMP-kinase (AMPK)-mediated, caspaseindependent apoptosis, via intracellular uptake of extracellular adenosine through ENTs, and caspase-dependent apoptosis, mediated by A1R and A3R $(154,155)$. ENTs passively transport nucleosides based on a concentration gradient (Figure 1) (156, 157). A1R and A3R signaling both inhibit adenylyl cyclase activity and can activate multiple downstream signaling pathways, including phospholipase C, producing inositol 1 , 
4, 5-triphosphate $\left(\mathrm{IP}_{3}\right)$ and diacylglycerol (DAG), mitogenactivated protein kinase (MAPK), and phosphoinositide 3-kinase (PI3K) (Figure 1) (158-160). A3R agonist, CF102, is in clinical trials for antitumor benefit in liver cancer (NCT02128958). $\mathrm{A} 3 \mathrm{R}$ is also reported to increase HIF-1 $\alpha$ through a nontranscription-dependent, non-HIF- $1 \alpha$ oxygen-dependent degradation mechanism in several cancer cell lines (161). Though the role of A3R-mediated upregulation of HIF- $1 \alpha$ is unclear, these data suggest A3R may both suppress and promote tumor progression. A2AR expression is increased in human GC tissue and correlates with poor tumor differentiation, advanced stage, lymph node positivity, and worse patient outcomes (162). Studies show A2AR, via PI3K-AKT-mTOR signaling, promotes GC cell stemness, EMT, and tumor cell migration and invasion (162). Altogether, more work is necessary to understand the role of CD73/extracellular adenosine in GC. Targeting specific adenosine receptors (e.g., A2AR) may be promising, but represents an area in need of more research.

\section{LIVER CANCER}

Liver cancer is the fourth most common cause of cancer death and sixth in terms of incidence worldwide (2). Ninety percentage of liver cancers are hepatocellular carcinoma (HCC) (163). Chronic liver disease (e.g., cirrhosis and fibrosis) is a major risk factor and most commonly caused by hepatitis B or C infection or long-term alcohol abuse (2, 164, 165). The 5-year survival rate for HCC is $18 \%$ (2). Treatment includes tumor resection, liver transplant, and targeted therapy (e.g., multi-kinase inhibitor, sorafenib) (166). However, 70\% of patients do not qualify for surgery, due to advance disease, and sorafenib therapy is limited in its benefit; patient survival is prolonged only by a few months (166). ICI therapy was recently approved as second-line therapy for HCC (Table 1) $(7,9)$. Other promising immunotherapies are in development and are aimed at boosting existing or de novo immune responses, including vaccines and oncolytic viruses, and combination ICI therapy (167). Anticipation awaits the results of NCT03298451, a phase 3 clinical trial assessing anti-PD-L1 and anti-CTLA-4 combination therapy vs. monotherapy as better first-line options than sorafenib [HIMALAYA trial, (NCT03298451)].

In recent years, HCC has been a platform for the discovery of novel biology for CD73 in human tumors (Table 2) $(168,169)$. Studies by Snider and colleagues (168) identified an alternative splicing variant of NT5E, NT5E-2 expressed in liver cirrhosis and HCC. NT5E-2 produces a protein product, CD73-short (CD73s), and is a human-specific isoform that lacks enzyme activity and is unable to dimerize due to the loss of exon 7 with splicing (168). CD73s expression is limited to the cytoplasm and complexes with CD73 to promote proteasome-dependent degradation of CD73 (168). In HCC human tissues, CD73s expression is 6-8fold higher compared to normal liver, whereas CD73 expression is downregulated by more than $90 \%$ (168). Accordingly, these studies indicate CD73s may be the major source of "CD73" overexpression in HCC. In contrast, other studies $(170,171)$ report CD73 is overexpressed in HCC and associates with poor tumor differentiation, microvascular invasion, and poor overall and recurrence-free survival (Figure 1) (170, 171). NT5E-2 expression was not assessed in these studies, which is a limitation. In line with CD73s expression, Sciarra et al. (172) especially noted significant cytoplasmic CD73 expression in tumors, particularly with invasive tumors (172) (Table 2).

Many immunohistochemistry data for high CD73 expressing tumors, including gastric and pancreatic cancer, show significant cytoplasmic staining of CD73 $(75,77)$. Current commercial antibodies are not marketed to distinguish between CD73 and CD73s. Thus, other human tumors with CD73 overexpression may overexpress CD73s. Notably, NT5E-2 is expressed at low levels in most normal human tissues and its expression increases with the onset of disease $(123,159)$. Currently, NT5E2 remains unstudied in other human tumors despite possible clinical implications. Similarly, recent studies by Alcedo et al. (169) report CD73 enzyme activity in HCC is significantly limited by aberrant glycosylation (169). The authors discovered that in HCC cells, unlike normal hepatocytes, CD73 carries abnormal N-linked glycosylation in its C-terminal catalytic domain, which greatly impairs the enzyme activity of CD73 (169). Aberrantly-glycosylated CD73 also showed to remain partially localized to the cytoplasm with golgi structural protein, GM130 (169). Importantly, these studies show that CD73 protein expression levels may not necessarily reflect its ability to generate extracellular adenosine. Studies by Snider et al. (168) and Alcedo et al. (169) are significant in that they demonstrate CD73 overexpression in human tumors can be misleading. Thus, CD73 immunohistochemistry may fall short in identifying patients likely to benefit the most from CD73 blockade therapy. As mentioned, commercial antibodies are unknown to be specific for recognizing CD73 vs. CD73s. Additionally, they are not primed for recognizing aberrant glycosylation. Instead, CD73 enzyme histochemistry is necessary, which is more challenging for clinical workups. These studies also raise questions as to how close preclinical studies of CD73/extracellular adenosine model human tumors. For instance, syngeneic and spontaneous mouse tumor models do not account for the biology of CD73s, which negatively regulates CD73 (168). A species-specific role of CD73 is also seen for arterial calcifications in humans and is not recapitulated in CD73-deficient mice $(173,174)$. CD73 downregulation in human tumors has been described in endometrial cancer. Its loss associates with more aggressive disease and poor overall survival (175). In normal endometrium, CD73-generated adenosine protects epithelial integrity, which CD73 loss and subsequently the loss of cell-cell adhesions promotes tumor progression (175). In contrast, in normal breast tissue, CD73 is expressed in myoepithelial cells as opposed to differentiated cells (e.g., acinar and ductal epithelial cells) (176). Myoepithelial cells are stem cell-like and exhibit highly invasive behavior similar to tumor cells (177). Consistent with this, CD73 is upregulated in cancer cells of triple-negative breast cancer (TNBC), which are tumors characterized by a gene expression signature similar to basal/myoepithelial cells (36, 177, 178). Accordingly, studies that reconcile tissue- and cell-specific roles for CD73 in normal GI tissues may help better understand CD73 in GI cancers $(179,180)$. Similar to 
endometrial cancer (175), CD73 is downregulated in cancer cells of bladder and prostate tumors and associates with poor prognosis $(181,182)$. The role of CD73 in bladder and prostate epithelium is unknown. Notably, CD39 deficiency promotes both induced and spontaneous autochthonous tumors in the liver (183).

For adenosine receptors, studies show A2AR signaling via $\mathrm{PI} 3 \mathrm{~K}-\mathrm{AKT}$ promotes HCC tumor growth and metastasis and is reversed by A2AR antagonist treatment (170). A2BR expression is increased in human HCC tissue and correlates with tumor progression and is likely due to hypoxia (184). HIF-1 $\alpha$ increases A2BR expression in HCC cells and cancer cell proliferation (184). Recent studies by Lan and colleagues (185) show HIF$1 \alpha$ 's induced expression of A2BR is essential in enriching breast cancer stem cells for the onset of recurrent disease (185). Studies linking A2BR to tumor progression include work in bladder (86), breast (186), colon (187), and prostate (188) cancer and involves A2BR activity on both immune and tumor cells. A2BR antagonist, ATL801, reduces metastases by more than $80 \%$ in mice, which is due to increased IFN- $\gamma$, IFNinducible chemokine CXCL10, a ligand for CXCR3, and tumorinfiltrating CXCR3 + T cells (86). Needless to say, interests in antagonizing A2BR in human tumors are rising. Studies by Vecchio et al. (188), in prostate cancer, describe a ligandindependent, constitutively active A2BR, which drives cancer cell proliferation (188). Importantly, these studies highlight an unappreciated view that adenosine receptors in tumors may not rely on CD73/extracellular adenosine. Aberrant ligandindependent $\mathrm{G}$ protein-coupled receptor constitutive activity is implicated in several cancers (188). In contrast, A3R expression is increased in human $\mathrm{HCC}$ and $\mathrm{A} 3 \mathrm{R}$ promotes cancer cell apoptosis (189). A3R agonist, CF102, is being evaluated as second-line therapy for HCC (NCT02128958). Increased overall survival is reported with NCT02128958 and phase 3 studies are being planned (190). Taken together, adenosine receptors as opposed to CD73 may be better predictive targets for therapeutic benefit in HCC.

\section{PANCREATIC CANCER}

Pancreatic cancer is predicted to become the second leading cause of cancer-related deaths in the United States by 2030 $(3,4)$. Ninety percentage of pancreatic tumors are pancreatic ductal adenocarcinoma (PDAC) while 3-5\% are neuroendocrine tumors (PNETs) (191). Smoking, heavy alcohol consumption, obesity, H. pylori infection, and chronic pancreatitis are risk factors (192). Prognosis is incredibly poor, approximately $70 \%$ of patients will succumb to the disease in the first year (193). The 5 -year survival rate is $9 \%$ (193). Standard of care for pancreatic cancer includes radiation therapy, chemotherapy, and targeted therapy (e.g., EGFR inhibitors) (192). The prevalence of therapy resistance to these treatments is a persistent problem. PDAC patients have not benefited from single agent or combination ICI therapy (194-196) despite increased expression of PDL1 in tumors (197-199). Significant efforts are underway to improve immunotherapy efficacy, including studies investigating regulatory B cell inhibition (e.g., Bruton's Tyrosine Kinase (BTK) inhibitors), IDO inhibition, and vaccine therapy (200). Though a predominant target in $\mathrm{B}$ cell malignancies, BTK in PDAC is shown to induce B cell- and macrophage-mediated $\mathrm{T}$ cell suppression, which BTK inhibitors (i.e., ibrutinib) restore T celldependent antitumor immunity and improve responsiveness to chemotherapy in preclinical studies (201). BTK inhibitors also produce an unexpected anti-fibrotic effect (202). PDAC cancers are rich in stromal cells and fibro-inflammatory reactions, which support chemotherapy resistance (203). A phase 3 clinical trial of ibrutinib in combination with chemotherapy in PDAC was recently completed (April 2019; NCT02436668) (204). Results are not yet publicly available.

Studies of CD73 in human PDAC tissue have only recently emerged (Table 2). CD73 is upregulated in PDAC compared to normal pancreatic tissue and correlates with increased tumor size, advanced stage, lymph node involvement, metastasis, and poor prognosis $(77,80,172)$. While PDAC tumors are $100 \%$ positive for CD73 expression (172), interesting staining patterns for CD73 are seen. Well- and moderately-differentiated PDAC cells express mixed membrane and cytoplasmic CD73 staining. CD73 staining intensity is low to moderate in these tumors (172). In contrast, poorly-differentiated PDAC cells have aberrant CD73 staining, including very strong cytoplasmic CD73 expression (172). The increase of cytoplasmic CD73 expression in PDAC is unclear. We previously mentioned the discovery of CD73s in HCC (168). Studies assessing NT5E-2 (CD73s) expression may help to better understand CD73 in PDAC. CD73 expression in acinar cell carcinomas (ACC) is rare (172). ACC comprises 1-2\% of pancreatic tumors and does not carry typical genomic alterations seen in PDAC, including KRAS and TP53 mutations (205), which is suggestive that CD73 expression in PDAC may be linked to KRAS and/or TP53 mutations. KRAS mutation occurs in nearly $100 \%$ of PDAC cases (206). In human colorectal cancer (CRC) and non-small cell lung cancer (NSCLC) tissue, CD73 staining is increased in KRAS mutant compared to wild-type tumor (207). KRAS alterations associate with increased CD73, CD39, A2AR, and A2BR gene expression in CRC and NSCLC cell lines, which correlates with anti-PD-1 resistance in KRAS mutant tumor models (207). Moreover, high CD73 expression and KRAS alterations associate with worse overall survival compared to patients with KRAS alterations and low CD73 expression tumors (207). EGFR alterations and high CD73 expression also associate with poor overall survival (TCGA pan-cancer) (207). EGFR alterations and KRAS mutations occur together in $67 \%$ of PDAC cases (208). Accordingly, EGFR alterations may also increase CD73 expression in PDAC. A positive association between CD73 expression and EGFR alterations is described in breast cancer (209).

CD73 expression (3+ staining) increases with aggressive disease in PDAC (172), which may be an indicator of an evolving or advancing immunosuppression phenotype. For instance, in PDAC, a decrease in CD8+ $\mathrm{T}$ cell infiltration into tumors is seen with the rise of infiltrating Tregs with disease progression (210). As mentioned, human Tregs rarely express cell surface CD73 $(93,94)$, and it is considered that 
CD73-generated extracellular adenosine from other sources [e.g., cells $(96)$ or exosomes $(97,98)]$ activate adenosine receptors on immune cells for immunosuppression. Accordingly, the coinciding increase of CD73 in PDAC cells may be significant in promoting extracellular adenosine-mediated immunosuppression. Other cells and cell-derived products possibly contributing are $\mathrm{CD} 4+\mathrm{CD} 73+\mathrm{T}$ cells, $\mathrm{B}$ cells, and CD39+ CD73+ exosomes (211). CD73+ PDAC and NSCLC cell-derived exosomes activate A3R on intratumor and peripheral mast cells, which promotes remodeling of the tumor microenvironment through increasing the expression of angiogenic factors $(212,213)$. Additionally, in PDAC models, tumor-infiltrating $\mathrm{CD} 11 \mathrm{~b}+\mathrm{CD} 103-\mathrm{DCs}$ promote tumor growth by inducing expansion of FoxP3 ${ }^{\text {neg }} \mathrm{CD} 39+\mathrm{CD} 73+$ tumor-promoting Tregs (214).

Pancreatic neuroendocrine tumors and carcinomas (PanNET/PanNEC) account for $1-10 \%$ of pancreatic tumors $(215,216)$. Thirty to fifty percent of PanNET/PanNEC express mild to moderate CD73 expression and associates with increased malignant potential, which is similar to gastrointestinal (GI)-NET/NECs (80, 172, 217). In GI-NET/NECs, CD73 expression positively correlates with PD-L1 expression (217), which possibly anti-PD-1/PD-L1 therapy with CD73 and/or A2AR blockade may benefit these patients. Increased expression of CD73 with PanNET also associates with cancer cell stemness (e.g., aldehyde dehydroxygenase expression) and aggressive behavior (80). Filippini et al. (218) recently reported a transplantable model of mouse pancreatic tumor organoids into immunocompetent mice that recapitulate human PDAC progression and that the system serves as a suitable model for immunophenotypic studies (218). The organoid-derived isographs induce the expression of many immunosuppressive/aggressive biomarkers with tumor development and evolution, including CD73 (218). Studies using such models may provide a significant understanding of CD73/extracellular adenosine signaling in immunosuppression and the immunoevolution of PDAC.

CD73 also shows to promote drug resistance and tumor growth in PDAC cells. For instance, high CD73 expression and low miR-30a-5p expression in PDAC cells result in chemotherapy (e.g., gemcitabine) resistance (77), and CD73 knockdown inactivates AKT and extracellular signal-regulated kinase (ERK) signaling and slows cancer cell growth (77). In contrast, studies show extracellular adenosine treatment in combination with AKT inhibitor, GSK690693, reduces PDAC growth and induces tumor cell apoptosis and senescence in patient-derived xenografts (PDX). Mechanistically, the intracellular uptake of extracellular adenosine via ENTs (Figure 1) appears important for this response, as dipyridamole (pan-ENT inhibitor) treatment remarkably recovers cell viability (219). The difference between these studies likely relates to the subcutaneous transplanting of tumors (77) vs. tumors transplanted to the tail of the pancreas (219). Indeed, for example, CD39 deficiency can promote the development of both induced and de novo tumors in the liver, which is in contrast to its role in antitumor immunity of subcutaneous transplanted tumors $(183,220)$. It is considered that the surrounding microenvironment and interaction with these cells by the tumor likely produce different responses and outcomes. In the next several years, adopting in-depth and detailed characterization of CD73/extracellular adenosine in immunocompetent, autochthonous pancreatic cancer models, humanized models, and human organoids will be essential for better understanding the possible therapeutic benefit of targeting CD73 and adenosine receptors in pancreatic tumors.

\section{COLORECTAL CANCER}

Colorectal cancer (CRC) is the third most common cancer and the second cause of cancer-related deaths worldwide (5). CRC incidence rates are declining in the United States and are stable in most other Western countries, whereas rates are rising in Eastern Asia and Eastern Europe and likely reflect the adoption of a Western lifestyle $(221,222)$. CRC risk factors include obesity, Western diet, lack of physical activity, excessive alcohol use, hereditary syndromes (e.g., Lynch syndrome), and smoking (223). Treatment includes surgery, combination chemotherapy, radiation therapy, and targeted therapy, including antibodies against VEGF/VEGFR or EGFR (224). Although advances in better screening and treatment have been made in the last decade, long-term survival remains poor for metastatic CRC patients. The 5-year survival rate is $<15 \%$ (225). ICI therapy was recently approved for refractory dMMR/MSI-H metastatic CRC (Table 1) $(8,10,11)$. Of CRC cases that are dMMR/MSI$\mathrm{H}$, only $4 \%$ are metastatic. Accordingly, several approaches, including IDO inhibitors, vaccine therapy, and combination ICI therapy are being studied to extend immunotherapy efficacy to more patients (226). A better understanding of CD73/adenosine receptor signaling in CRC may help in these efforts.

Early studies assessing CD73 in CRC were part of larger efforts examining enzymatic patterns of key enzymes involved with purine metabolism and salvage, including ADA, alkaline phosphatase, hypoxanthine-guanine phosphoribosyltransferase (Table 2) (227, 228). Studies by Camici et al. (227) reported no difference with CD73 enzyme activity between CRC and normal tissue (227). In contrast, Eroglu et al. (228) showed higher CD73 enzyme activity in tumors compared to normal tissue (228). No associations were found with high CD73 enzyme activity and poor clinical features. Instead, high CD73 enzyme activity was associated with well-differentiated tumors and low CD73 enzyme activity associated with poorlydifferentiated tumors (228). More recent studies show high CD73 expression correlates with poor tumor differentiation, lymph node involvement, advanced stage, and poor survival (78). In rectal cancer, CD73 expression in the different cell types carries different clinical prognosis (229). High CD73 expression in cancer cells and low CD73 expression in stromal cells associates with poor overall survival, whereas low CD73 expression in cancer cells and high CD73 expression in stromal cells is more favorable (229). Bladder cancer is similar. CD73 positive expression by epithelial cells predicts better progression-free survival and overall survival, whereas stromal cell CD73 positivity predicts poor outcome (230). Accordingly, 
these studies support that CD73 in tumors may suppress and promote tumor progression. Although unknown, targeting tumors with dual roles for CD73 may prove challenging for CD73 inhibitor therapy.

Tumor heterogeneity is likely one explanation for the reported differences of CD73 expression in CRC. CRC tumors carry significant inter- and intra-heterogeneity $(231,232)$, so much so that in recent years an international consortium was formed to establish a robust molecular and genetic classification scheme for CRC. These global efforts led to the development of the consensus molecular subtypes (CMS) (233). Accordingly, future efforts assessing CD73 expression to the CMS groups (e.g., CMS1, CMS2, CMS3, CMS4) may provide a better understanding of CD73 in CRC and the possible molecular and genetic alterations that drive its downregulation and/or overexpression. Indeed, high CD73 expression in CRC may be associated with CMS2 tumors. In CRC, CD73 is a predictive biomarker of patient response to anti-EGFR therapy (234). In line with this, the CMS2 group predicts tumors that are more responsive to anti-EGFR and anti-HER2 therapy (235). Also consistent is that CD73 promotes CRC cell proliferation and tumor growth through $\beta$-catenin (WNT)/cyclin D1 signaling (236) and CMS2 tumors are characterized by WNT and MYC signaling (233). KRAS mutations/alterations are likely also linked to CD73 expression in CRC; discussed previously in the section on PDAC (207). Thus, investigating CD73 expression in KRAS mutant tumors may provide additional insight. A focus on metastatic samples may also be important. Liver metastasis occurs in $50 \%$ CRC patients (237). Recently, studies have shown high CD73 expression associates with significantly shorter time to recurrence and poor survival (238). In renal cancer patients, an adenosine high (AdenoSighi) expression signature was identified in pretreatment biopsies and associated with clinical response to A2AR antagonism (124). Similar efforts in identifying biomarker signatures may provide greatly to improving immunotherapy efficacy in CRC.

In preclinical studies, CD73 deletion increases CD8 $+\mathrm{T}$ cells and IFN- $\gamma$ production to suppress the growth of MC-38 mouse colon cancer (32). The depletion of CD73 on CD4+ Foxp3+ Tregs also is significant in restoring antitumor immunity in this model (32). Similarly, CD39-deficient mice are resistant to MC-38 metastasis $(239,240)$. Whereas, overexpression of CD39 increases MC-26 mouse colon cancer cell metastasis to the liver (220). CD39 deletion does not increase the development of primary MC-26 orthotopic transplant tumors in heterozygous CD39 mice or mice transgenic for human CD39 compared to wild-type mice (220). Recent studies show support for cotargeting CD39 and CD73 in combination with ICI therapy and/or chemotherapy (44). Tumor-bearing mice benefit from increased antitumor immunity in these studies, which is due to the recovery of DC, macrophage, and effector $\mathrm{T}$ cell antitumor activity (44). In line with these studies, inhibiting CD39 or CD73 on MDSCs from CRC patients is effective in dampening the immunosuppressive activity of these cells (114).

Adenosine receptors may also be possible therapeutic targets. High A2AR expression associates with larger tumor size, increased tumor invasion, and higher TNM (TNM Classification of Malignant Tumors) stage in CRC (241). High A2AR expression also predicts poor patient survival and is positively correlated with PD-L1 expression (241). Consistent with the possible benefit of combined A2AR antagonist and ICI therapy (43, 68, 122, 123), studies with MC-38 cells, show A2AR antagonist, ciforadenant, combined with anti-PD-L1 or antiCTLA-4 therapy eliminates $90 \%$ of tumors in mice by restoring antitumor immunity (68). Notably, MC-38 cells are normally highly sensitive to ICI therapy $(37,123)$. Additionally, in many studies, MC-38 cells are grown subcutaneously. Accordingly, it is not known how close these preclinical studies model immunosuppression and immunotherapy efficacy for CRC. $\mathrm{A} 2 \mathrm{BR}$ is also upregulated in CRC and likely is linked to tumor hypoxia and progression (187). In vitro studies show A2BR expression is upregulated in CRC cells by hypoxia and promotes cancer cell proliferation, which is dampened by A2BR antagonism (187). A2BR antagonism also dampens A2BRmediated CD73 expression by cancer-associated fibroblasts (CAFs) and CAF-associated immunosuppression activity (242). $\mathrm{A} 3 \mathrm{R}$ is overexpressed in human CRC tissue and stimulates tumor growth via extracellular signal-regulated protein kinases 1 and 2 (ERK1/2) $(243,244)$. In contrast, studies also report A3R activity inhibits tumor growth by modulating glycogen

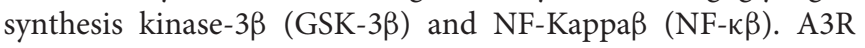
agonist treatment inhibits CRC cell proliferation, limits liver metastasis, and increases the cytotoxicity of chemotherapy (e.g., 5-fluorouracil) (245-247). Interestingly, treatment of CRC cells with caffeine, a non-selective adenosine receptor antagonist, inhibits A3R-mediated stabilization of HIF- $1 \alpha$ (248). It is unclear if $\mathrm{HIF}-1 \alpha$ mediated by $\mathrm{A} 3 \mathrm{R}$ promotes tumor progression or antitumor activity. HIFs are described to have pro- and antitumor activity in CRC (249). Moreover, overexpression of HIF-1 $\alpha$ does not increase CRC tumorigenesis and does not result in spontaneous tumor formation in mice (250). Taken together, while many adenosine pathway members show evidence for possible therapeutic targeting in CRC, detailed studies in human tumors and relevant preclinical models are greatly needed.

\section{CLINICAL IMPLICATIONS}

Inhibiting CD73 (and/or A2AR) restores antitumor immunity in many preclinical studies with combination approaches showing superior efficacy. Accordingly, several clinical trials inhibiting CD73 (e.g., antibodies against CD73 or small molecule inhibitors) in combination with ICI therapy, A2AR antagonism, targeted therapy, and/or chemotherapy are underway (Table 3). Preliminary safety profiles report BMS-986179, an anti-CD73 humanized monocolonal antibody, and its combination with nivolumab (anti-PD-1 therapy) to be well-tolerated in patients (NCT02754141) (251). Recent studies in renal cell cancer (RCC) reported the feasibility and safety of A2AR antagonist, ciforadenant (124). Similar to preclinical studies, durable clinical benefit was associated with increased recruitment of CD8+ $\mathrm{T}$ cells (124). Additionally, combination therapy (ciforadenant and anti-PD-L1 therapy) showed benefit in patients who had progressed on anti-PD-1/PD-L1 therapy. Notably, patients in 
TABLE 3 | Summary of clinical trials for CD73, A2AR, and A2BR in cancer.

\begin{tabular}{|c|c|c|c|c|c|c|c|c|}
\hline $\begin{array}{l}\text { Adenosine } \\
\text { pathway target }\end{array}$ & Drug(s) & Target(s) & $\begin{array}{l}\text { Therapy modality } \\
\text { (adenosine pathway) }\end{array}$ & Phase & Details & Disease & Status & $\begin{array}{l}\text { ClinicalTrials.gov } \\
\text { Identifier }\end{array}$ \\
\hline \multirow[t]{11}{*}{ CD73 } & $\begin{array}{l}\text { LY3475070 } \\
\text { Pembrolizumab }\end{array}$ & $\begin{array}{l}\text { CD73 } \\
\text { PD-1 }\end{array}$ & $\begin{array}{l}\text { LY3475070: } \\
\text { CDD3 Small } \\
\text { Molecule Inhibitor }\end{array}$ & Phase 1 & $\begin{array}{l}\text { Cohort A: LY3475070 administered orally } \\
\text { Cohort B: : Y Y3475070 + Pembrolizumab administered IV } \\
\text { Cohort C1: LY3475070 + Pembrolizumab administered IV } \\
\text { Cohort C2 LY3475070 administered orally } \\
\text { Cohort D1 L134575070 + Pembroizumab administered IV } \\
\text { Cohort D2: LY3475070 administered orally } \\
\text { Cohort E: LY3475070 + Pembrolizumab administered IV }\end{array}$ & $\begin{array}{l}\text { Advanced Solid } \\
\text { Malignancies }\end{array}$ & Recruiting & NCT04148937 \\
\hline & $\begin{array}{l}\text { Oleclumab } \\
\text { (MEDI9447) } \\
\text { Durvalumab } \\
\text { (MEDI4736) }\end{array}$ & $\begin{array}{l}\text { CD73 } \\
\text { PD-L1 }\end{array}$ & $\begin{array}{l}\text { Oleclumab: } \\
\text { CD73 Humanized } \\
\text { Monoclonal } \\
\text { Antibody }\end{array}$ & $\begin{array}{l}\text { Phase } 1 \\
\text { Phase } 2\end{array}$ & $\begin{array}{l}\text { Phase I and Phase || Arm A: Paclitaxel, Carboplatin, Durvalumab, + Oleclumab } \\
\text { Phase || Amm B: Paclitaxel, Carboplatin, + Durvalumab }\end{array}$ & $\begin{array}{l}\text { Triple Negative } \\
\text { Breast Cancer }\end{array}$ & Recruiting & NCT03616886 \\
\hline & $\begin{array}{l}\text { Oleclumab } \\
\text { (MEDII9447) } \\
\text { Durvalumab }\end{array}$ & $\begin{array}{l}\text { CD73 } \\
\text { PD-L1 }\end{array}$ & $\begin{array}{l}\text { Oleclumab: } \\
\text { CD73 Humanized } \\
\text { Monoclonal } \\
\text { Antibody }\end{array}$ & Phase 2 & $\begin{array}{l}\text { Experimental: Chemotherapy and radiation } \\
\text { Experimental: Chemotherapy and pre-operative radiotherapy + Durvalumab } \\
\text { Experimental: Chemotherapy and pre-operative radiotherapy + Durvalumab } \\
\text { and Oleclumab }\end{array}$ & $\begin{array}{l}\text { Luminal B } \\
\text { (Breast Cancer) }\end{array}$ & Recruiting & NCT03875573 \\
\hline & $\begin{array}{l}\text { Oleclumab } \\
\text { (MEDI9447) } \\
\text { Durvalumab }\end{array}$ & $\begin{array}{l}\text { CD73 } \\
\text { PD-L1 }\end{array}$ & $\begin{array}{l}\text { Oleclumab: } \\
\text { CD73 Humanized } \\
\text { Monoclonal } \\
\text { Antibody }\end{array}$ & Phase 1 & $\begin{array}{l}\text { Experimental: Monotherapy, Oleclumab } \\
\text { Experimental: Combination, Oleclumab and Durvalumab }\end{array}$ & Solid Tumors & $\begin{array}{l}\text { Active, not } \\
\text { Recruiting }\end{array}$ & NCT02503774 \\
\hline & $\begin{array}{l}\text { TJ004309 } \\
\text { Atezolizumab }\end{array}$ & $\begin{array}{l}\text { CD73 } \\
\text { PD-L1 }\end{array}$ & $\begin{array}{l}\text { TJ004309: } \\
\text { CD73 Humanized } \\
\text { Monoclonal } \\
\text { Antibody }\end{array}$ & Phase 1 & Dose escalated TJ004309 + Atezolizumab & $\begin{array}{l}\text { Solid Tumors } \\
\text { Metastatic Cancer }\end{array}$ & Recruiting & NCT03835949 \\
\hline & $\begin{array}{l}\text { Oleclumab } \\
\text { (MEDII9447) } \\
\text { Durvalumab } \\
\text { AZD9150 } \\
\text { AZDE738 } \\
\text { Vistuestib } \\
\text { Olaparib } \\
\text { Trasutzumab } \\
\text { Cediranib }\end{array}$ & $\begin{array}{l}\text { CD73 } \\
\text { PD-L1 } \\
\text { STAT3 } \\
\text { ATR } \\
\text { mTOR } \\
\text { PARP } \\
\text { HER2 } \\
\text { VEGFR }\end{array}$ & $\begin{array}{l}\text { Oleclumab: } \\
\text { CD73 Humanized } \\
\text { Monoclonal } \\
\text { Antibody }\end{array}$ & Phase 2 & $\begin{array}{l}\text { Experimental: Durvalumab + Olaparib } \\
\text { Experimental: Durvalumab + AZD9150 } \\
\text { Experimental : Durvalumab + AZD6738 } \\
\text { Experimental Dirvalumab + Vistusertib } \\
\text { Experimental: Durvalumab + Oleclumab } \\
\text { Experimental: Durvalumab + Trastuzumab } \\
\text { Experimental: Durvalumab + Cediranib }\end{array}$ & $\begin{array}{l}\text { Non-Small Cell Lung } \\
\text { Cancer }\end{array}$ & Recruiting & NCT03334617 \\
\hline & $\begin{array}{l}\text { Oleclumab } \\
\text { (MEDI9447) } \\
\text { Durvalumab } \\
\text { Capivasertib } \\
\text { Danvatirsen } \\
\text { Paclitaxel }\end{array}$ & $\begin{array}{l}\text { CD73 } \\
\text { PD-L1 } \\
\text { AKT } \\
\text { STAT3 } \\
\text { Chemotherapy }\end{array}$ & $\begin{array}{l}\text { Oleclumab: } \\
\text { CD73 Humanized } \\
\text { Monoclonal } \\
\text { Antibody }\end{array}$ & $\begin{array}{l}\text { Phase } 1 \\
\text { Phase } 2\end{array}$ & 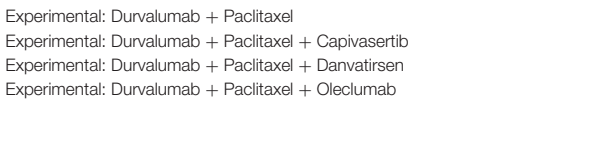 & $\begin{array}{l}\text { Triple Negative } \\
\text { Breast Cancer }\end{array}$ & Recruiting & NCT03742102 \\
\hline & $\begin{array}{l}\text { Oleclumab } \\
\text { (MEDI9447) } \\
\text { Durvalumab } \\
\text { Gemcitabine } \\
\text { Nab-paclitaxel } \\
\text { Oxaliplatin } \\
\text { Leecovorin } \\
\text { 5-FU }\end{array}$ & $\begin{array}{l}\text { CD73 } \\
\text { PD-L1 } \\
\text { Chemotherapy }\end{array}$ & $\begin{array}{l}\text { Oleclumab: } \\
\text { CD73 Humanized } \\
\text { Monoclonal } \\
\text { Antibody }\end{array}$ & $\begin{array}{l}\text { Phase } 1 \\
\text { Phase } 2\end{array}$ & $\begin{array}{l}\text { Arm A1: Gemcitabine + Nab-paclitaxel } \\
\text { Arm A2: Oleclumab + Gemcitabine + Nab-paclitaxel } \\
\text { Arm A3: Oleclumab + Durvalumab + Gemcitabine/Nab-paclitaxel } \\
\text { Arm B: Oxalilatin + Leucovorin + 5-FU (mFOLFOX) } \\
\text { Amm B2: Oleclumab + mFOLFOX }\end{array}$ & $\begin{array}{l}\text { Carcinoma } \\
\text { Metastatic Pancreatic } \\
\text { Adenocarcinoma }\end{array}$ & $\begin{array}{l}\text { Active, not } \\
\text { Recruiting }\end{array}$ & NCT03611556 \\
\hline & $\begin{array}{l}\text { Oleclumab } \\
\text { (MEDI9447) } \\
\text { Durvalumab }\end{array}$ & $\begin{array}{l}\text { CD73 } \\
\text { PD-L1 }\end{array}$ & $\begin{array}{l}\text { Oleclumab: } \\
\text { CD73 Humanized } \\
\text { Monoclonal Antibody }\end{array}$ & Phase 1 & $\begin{array}{l}\text { Experimental: Monotherapy, Durvalumab } \\
\text { Experimental: Combination, Durvalumab + Oleclumab }\end{array}$ & $\begin{array}{l}\text { Muscle Invasive } \\
\text { Bladder Cancer }\end{array}$ & Recruiting & NCT03773666 \\
\hline & $\begin{array}{l}\text { BMS-986179 } \\
\text { Nivolumab } \\
\text { rHUPH20 }\end{array}$ & $\begin{array}{l}\mathrm{CD} 73 \\
\text { PD-1 } \\
\text { Hyaluronidase }\end{array}$ & $\begin{array}{l}\text { Oleclumab: } \\
\text { CD73 Humanized } \\
\text { Monoclonal } \\
\text { Antibody }\end{array}$ & $\begin{array}{l}\text { Phase } 1 \\
\text { Phase } 2\end{array}$ & $\begin{array}{l}\text { Arm A: Monotherapy, BMS-986179 } \\
\text { Arm B: : Ombinition Therapy, BMS }-986179+\text { Nivolumab } \\
\text { Arm C: Combination Therapy, BMS-986179 + rHUPH20 }\end{array}$ & $\begin{array}{l}\text { Malignant Solid } \\
\text { Tumor }\end{array}$ & Recruiting & NCT02754141 \\
\hline & $\begin{array}{l}\text { Oleclumab } \\
\text { (MEDI9447) } \\
\text { MEDI0562 } \\
\text { Durvalumab } \\
\text { Tremelilumab }\end{array}$ & $\begin{array}{l}\text { CD73 } \\
\text { OX40 } \\
\text { PD-L1 } \\
\text { CTLA-4 }\end{array}$ & $\begin{array}{l}\text { Oleclumab: } \\
\text { CD73 Humanized } \\
\text { Monoclonal } \\
\text { Antibody }\end{array}$ & Phase 2 & $\begin{array}{l}\text { Cohort A: Oleclumab + Durvalumab } \\
\text { Cohort B: MEDDDo562 + Durvalumab } \\
\text { Cohort C: MEDI0562 + Tremelimumab }\end{array}$ & Ovarian Cancer & Recruiting & NCT03267589 \\
\hline
\end{tabular}


TABLE 3 | Continued

\begin{tabular}{|c|c|c|c|c|c|c|c|c|}
\hline $\begin{array}{l}\text { Adenosine } \\
\text { pathway target }\end{array}$ & Drug(s) & Target(s) & $\begin{array}{l}\text { Therapy modality } \\
\text { (adenosine pathway) }\end{array}$ & Phase & Details & Disease & Status & $\begin{array}{l}\text { ClinicalTrials.gov } \\
\text { Identifier }\end{array}$ \\
\hline \multirow[t]{5}{*}{ CD73 A2AR } & $\begin{array}{l}\text { CPI-006 } \\
\text { Ciforadenant } \\
\text { (CPI-444) } \\
\text { Pembrolizumab }\end{array}$ & $\begin{array}{l}\text { CD73 } \\
\text { A2AR } \\
\text { PD-1 }\end{array}$ & $\begin{array}{l}\text { CPI-006: } \\
\text { CD73 Humanized } \\
\text { Monoclonal } \\
\text { Antibody } \\
\text { Ciforadenant: } \\
\text { A2AR Antagonist }\end{array}$ & Phase 1 & $\begin{array}{l}\text { Cohort 1a: (escalating doses) CPI-006 } \\
\text { Cohort 1b: (escalating doses) CPI-006 + Ciforadenant } \\
\text { Cohort 1c: (escalating doses) CPI-006 + Pembrolizumab } \\
\text { Cohort 2a: (selective dose) CPP-006 } \\
\text { Cohort 2b: (selective dose) CPI-006 + Ciforadenant } \\
\text { Cohort 2c: (selective doses) CPI-006 + Pembrolizumab }\end{array}$ & $\begin{array}{l}\text { Non-Small Cell Lung Cancer } \\
\text { Renal Cell Cancer } \\
\text { Colorectal Cancer } \\
\text { Triple Negative Breast Cancer } \\
\text { Cervical Cancer } \\
\text { Ovarian Cancer } \\
\text { Pancreatic Cancer } \\
\text { Endometrial Cancer } \\
\text { Sarcoma } \\
\text { Squamous Cell Carcinoma of the } \\
\text { Head and Neck } \\
\text { Bladder Cancer } \\
\text { Metastatic Castration Resistant } \\
\text { Prostate Cancer } \\
\text { Non-hodgkin Lymphoma }\end{array}$ & Recruiting & NCT03454451 \\
\hline & $\begin{array}{l}\text { Oleclumab } \\
\text { (MEDI9447) } \\
\text { AZD4635 } \\
\text { Durvalumab }\end{array}$ & $\begin{array}{l}\text { CD73 } \\
\text { A2AR } \\
\text { PD-L1 }\end{array}$ & $\begin{array}{l}\text { Oleclumab: } \\
\text { CD73 Humanized } \\
\text { Monoclonal } \\
\text { Antibody } \\
\text { AZD4635: } \\
\text { A2AR Antagonist }\end{array}$ & Phase 2 & $\begin{array}{l}\text { Module 1: Drug: AZD4635; Drug: Durvalumab } \\
\text { Module 2: Drug: AZD4635; Drug: Oleclumab }\end{array}$ & $\begin{array}{l}\text { Prostate Cancer } \\
\text { Metastatic } \\
\text { Castration-Resistant } \\
\text { Prostate Cancer }\end{array}$ & Recruiting & NCT04089553 \\
\hline & $\begin{array}{l}\text { Oleclumab } \\
\text { (MEDD19447) } \\
\text { AZD4635 } \\
\text { Osimertinib }\end{array}$ & $\begin{array}{l}\text { CD73 } \\
\text { A2AR } \\
\text { EGFR }\end{array}$ & $\begin{array}{l}\text { Oleclumab: } \\
\text { CD73 Humanized } \\
\text { Monoclonal } \\
\text { Antibody } \\
\text { AZD4635: } \\
\text { A2AR Antagonist }\end{array}$ & $\begin{array}{l}\text { Phase } 1 \\
\text { Phase } 2\end{array}$ & $\begin{array}{l}\text { Arm A: MEDI9447 + Osimertinin } \\
\text { Arm B: MEDI9447 + AZD4635 }\end{array}$ & $\begin{array}{l}\text { Non-Small Cell Lung } \\
\text { Cancer }\end{array}$ & Recruiting & NCT03381274 \\
\hline & $\begin{array}{l}\text { NZV930 } \\
\text { NR178 } \\
\text { PDR001 }\end{array}$ & $\begin{array}{l}C D 73 \\
\text { A2AR } \\
\text { PD-1 }\end{array}$ & $\begin{array}{l}\text { NZV930: } \\
\text { CD73 Humanized } \\
\text { Monoclonal } \\
\text { Antibody } \\
\text { NIR178: } \\
\text { A2AR Antagonist }\end{array}$ & Phase 1 & $\begin{array}{l}\text { Experimental: NZV930 } \\
\text { Experimental: NZV930 + PDR001 } \\
\text { Experimental: NZ930 + NR1R178 } \\
\text { Experimental: NZV930, NR178, PDR001 }\end{array}$ & $\begin{array}{l}\text { Non-small Cell Lung } \\
\text { Cancer (NSCLC) } \\
\text { Triple Negative } \\
\text { Breast Cancer } \\
\text { Pancreatic Ductal } \\
\text { Adenocarcinoma } \\
\text { Colorectal Cancer } \\
\text { Microsatellite Stable } \\
\text { Ovarian Cancer } \\
\text { Renal Cell } \\
\text { Carcinoma }\end{array}$ & Recruiting & NCT03549000 \\
\hline & $\begin{array}{l}\text { Oleclumab } \\
\text { (MEDI9447) } \\
\text { AZD4635 } \\
\text { Durvalumab } \\
\text { Abiraterone } \\
\text { Acetate } \\
\text { Enzalutamide } \\
\text { Docetaxel }\end{array}$ & $\begin{array}{l}\text { CD73 } \\
\text { A2AR } \\
\text { PD-L1 } \\
\text { Hormone } \\
\text { Therapy } \\
\text { Chemotherapy }\end{array}$ & $\begin{array}{l}\text { Oleclumab: } \\
\text { CD73 Humanized } \\
\text { Monoclonal } \\
\text { Antibody } \\
\text { AZD4635: } \\
\text { A2AR Antagonist }\end{array}$ & Phase 1 & $\begin{array}{l}\text { Experimental: Arm A: AZD4635 monotherapy as nanoparticle suspension } \\
125 \mathrm{mg} \text { BID } \\
\text { Experimental: Arm B: AZD4635 monotherapy as nanoparticle suspension } \\
75 \mathrm{mg} \text { QD } \\
\text { Experimental: Arm C: AZD4635 monotherapy as nanoparticle suspension } \\
100 \mathrm{mg} \text { QD } \\
\text { Experimental: Arm D: AZD4635 as nanoparticle suspension } 75 \mathrm{mg} \text { QD plus } \\
\text { Durvalumab } \\
\text { Experimental: Arm E: AZD4635 as nanoparticle suspension } 100 \mathrm{mg} \text { QD plus } \\
\text { Durvalumab } \\
\text { Experimental: Arm EA: AZD4635 as nanoparticle suspension plus Enzzalutamide } \\
\text { Experimental: Arm AA: AZD4635 as nanoparticle suspension plus Abiraterone } \\
\text { Acetate } \\
\text { Experimental: Arm F: AZD4635 as nanoparticle suspension plus Durvaluamb in } \\
\text { patients post immunotherapy with non-small cell lung cancer } \\
\text { Experimental: Arm G: AZD4635 monotherapy as nanoparticle suspension in } \\
\text { patients post immunotherapy with non-small cell lung cancer } \\
\text { Experimental: Arm H: AZDD635 monotherapy as nanoparticle suspension in } \\
\text { patients post immunotherapy with other solid tumors } \\
\text { Experimental: Arm I: AZD4635 as nanoparticle suspension plus Durvalumab in } \\
\text { immunotherapy naive patients with metastatic castration resistant prostate } \\
\text { cancer } \\
\text { Experimental: Arm J: AZD4635 as nanoparticle suspension plus Durvalumab in } \\
\text { immunotherapy naive patients with metastatic castration resistant prostate } \\
\text { cancer }\end{array}$ & $\begin{array}{l}\text { Advanced Solid } \\
\text { Malignancies } \\
\text { Non-Small Cell Lung } \\
\text { Cancer } \\
\text { Metastatic Castrate-Resistant } \\
\text { Prostate Carcinoma } \\
\text { Colorectal } \\
\text { Carcinoma }\end{array}$ & Recruiting & NCT02740985 \\
\hline
\end{tabular}




\begin{tabular}{|c|c|c|c|c|c|c|c|c|}
\hline $\begin{array}{l}\text { Adenosine } \\
\text { pathway target }\end{array}$ & Drug(s) & Target(s) & $\begin{array}{l}\text { Therapy modality } \\
\text { (adenosine pathway) }\end{array}$ & Phase & Details & Disease & Status & $\begin{array}{l}\text { ClinicalTrials.gov } \\
\text { Identifier }\end{array}$ \\
\hline & & & & & 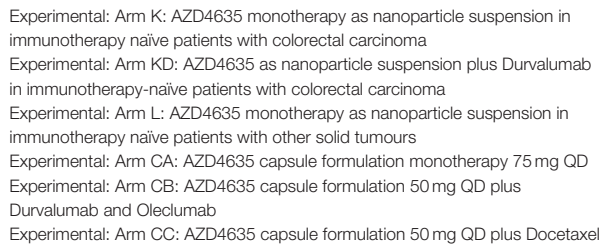 & & & \\
\hline \multirow[t]{5}{*}{ A2AR } & $\begin{array}{l}\text { NIR178 } \\
\text { PDR001 }\end{array}$ & $\begin{array}{l}\text { A2AR } \\
\text { PD-1 }\end{array}$ & $\begin{array}{l}\text { NIR178: } \\
\text { A2AR Antagonist }\end{array}$ & Phase 2 & $\begin{array}{l}\text { Experimental (1): NR178 + PDR001 } \\
\text { Experimental (2): NR178 BID Intermittent + PDR001 } \\
\text { Experimental (3): Part 3, initiation of part } 3 \text { will depend on results from parts } 1 \\
\text { and } 2 \\
\text { Experimental (4): Japanese safety run-in part, two different dosing schedules of } \\
\text { NIR178 will be explored }\end{array}$ & $\begin{array}{l}\text { Non-small Cell Lung Cancer } \\
\text { Renal Cell Cancer } \\
\text { Pancreatic Cancer } \\
\text { Urothelial Cancer } \\
\text { Head and Neck Cancer } \\
\text { Diffused Large B Cell Lymphoma } \\
\text { Microsatellite Stable Colon } \\
\text { Cancer } \\
\text { Triple Negative Breast Cancer } \\
\text { Melanoma }\end{array}$ & Recruiting & NCT03207867 \\
\hline & $\begin{array}{l}\text { PBF-509 } \\
\text { PDR001 }\end{array}$ & $\begin{array}{l}\text { A2AR } \\
\text { PD-1 }\end{array}$ & $\begin{array}{l}\text { PBF-509: } \\
\text { A2AR Antagonist }\end{array}$ & $\begin{array}{l}\text { Phase } 1 \\
\text { Phase } 2\end{array}$ & 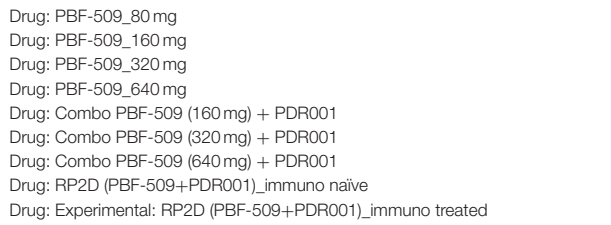 & Non-small Cell Lung Cancer & Recruiting & NCT02403193 \\
\hline & $\begin{array}{l}\text { NIR178 } \\
\text { Spartalizumab } \\
\text { LAG525 } \\
\text { Capmatinib } \\
\text { MCS110 } \\
\text { Canakinumab }\end{array}$ & $\begin{array}{l}\text { A2AR } \\
\text { PD-1 } \\
\text { LAG-3 } \\
\text { C-Met } \\
\text { MLCSF } \\
\text { IL-1 } 1 \beta\end{array}$ & $\begin{array}{l}\text { NIR178: } \\
\text { A2AR Antagonist }\end{array}$ & Phase 1 & $\begin{array}{l}\text { Experimental: Spartalizumab + LAG525 + NIR178 } \\
\text { Experimental: Spartalizumab + LAG525 + Capmatinib } \\
\text { Experimentall: spartalizumab + LAG525 + MCS11 } \\
\text { Experimental: spartalizumab + LAG525 + Canakinumab }\end{array}$ & $\begin{array}{l}\text { Triple Negative } \\
\text { Breast Cancer }\end{array}$ & Recruiting & NCT03742349 \\
\hline & $\begin{array}{l}\text { Ciforadenant } \\
\text { (CPI-444) } \\
\text { Atezolizumab }\end{array}$ & $\begin{array}{l}\text { A2AR } \\
\text { PD-L1 }\end{array}$ & $\begin{array}{l}\text { Ciforadenant: } \\
\text { A2AR Antagonist }\end{array}$ & Phase 1 & $\begin{array}{l}\text { Experimental: Ciforadenant, } 100 \mathrm{mg} \text { orally twice daily for the first } 14 \text { days of } \\
\text { each } 28 \text {-day cycle } \\
\text { Experimental: Ciforadenant, } 100 \mathrm{mg} \text { orally twice daily for } 28 \text { days of each } \\
28 \text {-day cycle } \\
\text { Experimental: Ciforadenant, } 200 \mathrm{mg} \text { orally once daily for the first } 14 \text { days of } \\
\text { each } 28 \text {-day cycle } \\
\text { Experimental: Ciforadenant + Atezolizumab } \\
\text { Experimental: Ciforadenant, start with } 150 \mathrm{mg} \text { orally twice daily for } 28 \text {-day } \\
\text { cycles; then, increase increments by } 100 \mathrm{mg} / \text { day for } 6 \text { dose levels }\end{array}$ & $\begin{array}{l}\text { Non-Small Cell Lung Cancer } \\
\text { Malignant Melanoma Renal Cell } \\
\text { Cancer } \\
\text { Triple Negative Breast Cancer } \\
\text { Colorectal Cancer } \\
\text { Bladder Cancer } \\
\text { Metastatic Castration Resistant } \\
\text { Prostate Cancer }\end{array}$ & Recruiting & NCT02655822 \\
\hline & $\begin{array}{l}\text { Ciforadenant } \\
\text { (CPI-444) } \\
\text { Atezolizumab } \\
\text { Cobimetinib } \\
\text { Ro69586888 } \\
\text { Docetaxel } \\
\text { Pemetrexed } \\
\text { Carboplatin } \\
\text { Gemcitabine } \\
\text { Linagliptin } \\
\text { Tocilizumab } \\
\text { Ipatasertib } \\
\text { Idasanutlin }\end{array}$ & $\begin{array}{l}\text { A2AR } \\
\text { PD-L1 } \\
\text { MEK } \\
\text { CEA } \\
\text { Chemotherapy } \\
\text { IL-6R } \\
\text { AKT } \\
\text { MDM2 }\end{array}$ & $\begin{array}{l}\text { Ciforadenant: } \\
\text { A2AR Antagonist }\end{array}$ & $\begin{array}{l}\text { Phase } 1 \\
\text { Phase } 2\end{array}$ & 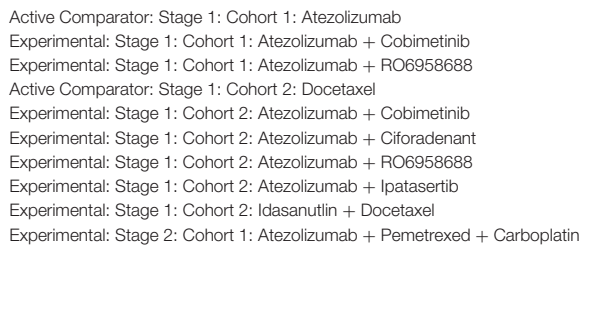 & Carcinoma, Non-Small-Cell Lung & Recruiting & NCT03337698 \\
\hline
\end{tabular}


TABLE 3 | Continued

\begin{tabular}{|c|c|c|c|c|c|c|c|c|}
\hline $\begin{array}{l}\text { Adenosine } \\
\text { pathway target }\end{array}$ & Drug(s) & Target(s) & $\begin{array}{l}\text { Therapy modality } \\
\text { (adenosine pathway) }\end{array}$ & Phase & Details & Disease & Status & $\begin{array}{l}\text { ClinicalTrials.gov } \\
\text { Identifier }\end{array}$ \\
\hline \multirow[t]{5}{*}{ A2AR A2BR } & $\begin{array}{l}\text { AB928 } \\
\text { IPI-549 } \\
\text { Doxorubicin } \\
\text { Paclitaxel }\end{array}$ & $\begin{array}{l}\text { A2AR/A2BR } \\
\text { PI3Ky } \\
\text { Chemotherapy }\end{array}$ & $\begin{array}{l}\text { AB928: } \\
\text { Dual A2AR and } \\
\text { A2BR Antagonist }\end{array}$ & Phase 1 & $\begin{array}{l}\text { Experimental: Dose Escalation-Arm A, AB928 + Pegylated Liposomal } \\
\text { Doxorubicicin } \\
\text { Experimental: Dose Escalation-Arm B, AB928 + Nanoparticle Albumin-bound } \\
\text { Paclitaxel } \\
\text { Experimental: Dose Escalation-Arm C, AB928 + Pegylated Liposomal } \\
\text { Doxorubicin + Nanoparticle Albuminin-bound Paclitaxel } \\
\text { Experimental: Dose Expansion-TNBC-Arm 1, dose from Arm A for AB928 + } \\
\text { Pegylated Liposomal Doxorubicin } \\
\text { Experimental: Dose Expansion-Ovarian-Arm 2, dose from Arm A for AB928 + } \\
\text { Pegylated Liposomal Doxorubicin } \\
\text { Experimental: Dose Expansion-TNBC-Amm 3, dose from Arm B for AB928 + } \\
\text { Nanoparticle Albumin-bound Paclitaxel } \\
\text { Experimental: Dose Expansion-TNBC-Amm 4, dose from Arm C for AB928 + } \\
\text { IPl-549 + Pegylated Liposomal Doxorubicin }\end{array}$ & $\begin{array}{l}\text { Triple Negative } \\
\text { Breast Cancer } \\
\text { (TNBC) } \\
\text { Ovarian Cancer }\end{array}$ & Recruiting & NCT03719326 \\
\hline & $\begin{array}{l}\text { AB928 } \\
\text { mFOLFOX }\end{array}$ & $\begin{array}{l}\text { A2AR/A2BR } \\
\text { Chemotherapy }\end{array}$ & $\begin{array}{l}\text { AB928: } \\
\text { Dual A2AR and } \\
\text { A2BR Antagonist }\end{array}$ & Phase 1 & $\begin{array}{l}\text { Experimental: Dose Escalation, AB928 + mFOLFOX Experimental: Dose } \\
\text { Expansion-GE, dose from escalation for AB928 + mFOLFOX Experimental: } \\
\text { Dose Expansion-CRC, dose from escalation for AB928 + mFOLFOX }\end{array}$ & $\begin{array}{l}\text { GastroEsophageal } \\
\text { Cancer (GE) } \\
\text { Colorectal Cancer } \\
\text { (CRC) }\end{array}$ & Recruiting & NCT03720678 \\
\hline & $\begin{array}{l}\text { AB928 } \\
\text { Zimberelimab } \\
\text { (AB122) }\end{array}$ & $\begin{array}{l}\text { A2AR/A2BR } \\
\text { PD-1 }\end{array}$ & $\begin{array}{l}\text { AB928: } \\
\text { Dual A2AR and } \\
\text { A2BR Antagonist }\end{array}$ & Phase 1 & $\begin{array}{l}\text { Experimental: Dose Escalation, AB928 + fixed dose of Zimberelimab (AB122) } \\
\text { Experimental: Dose Expansion-Renal Cell Carcinoma, recommended dose for } \\
\text { expansion AB928 + Zimberelimab (AB122) } \\
\text { Experimental: : } 0 \text { ose Expansion, recommended dose for expansion AB928 + } \\
\text { Zimberelimab (AB122) }\end{array}$ & $\begin{array}{l}\text { Non-small Cell Lung Cancer } \\
\text { Squamous Cell Carcinoma of the } \\
\text { Head and Neck } \\
\text { Breast Cancer } \\
\text { Colorectal Cancer } \\
\text { Melanoma Bladder Cancer } \\
\text { Ovarian Cancer } \\
\text { Endometrial Cancer } \\
\text { Merkel Cell Carcinoma } \\
\text { Gastrossophageal Cancer } \\
\text { Renal Cell Carcinoma } \\
\text { Castration-resistant Prostate } \\
\text { Cancer }\end{array}$ & Recruiting & NCT03629756 \\
\hline & $\begin{array}{l}\text { AB928 } \\
\text { AB154 } \\
\text { Zimberelimab } \\
\text { (AB122) }\end{array}$ & $\begin{array}{l}\text { A2AR/A2BR } \\
\text { TIGIT } \\
\text { PD-1 }\end{array}$ & $\begin{array}{l}\text { AB928: } \\
\text { Dual A2AR and } \\
\text { A2BR Antagonist }\end{array}$ & Phase 2 & $\begin{array}{l}\text { Experimental: Arm 1, Zimberelimab } \\
\text { Experimental: Arm 2, AB154 + Zimberelimab } \\
\text { Experimental: Arm 3, AB928 + AB154 + Zimberelimab }\end{array}$ & $\begin{array}{l}\text { Non-Small Cell Lung Cancer } \\
\text { Non-squamous Non-Small Cell } \\
\text { Lung Cancer } \\
\text { Squamous Non-Small Cell Lung } \\
\text { Cancer } \\
\text { Lung Cancer }\end{array}$ & Recruiting & NCT04262856 \\
\hline & $\begin{array}{l}\text { AB928 } \\
\text { Zimberelimab } \\
\text { (AB122) } \\
\text { Carboplatin } \\
\text { Pemetrexed } \\
\text { Pembrolizumab }\end{array}$ & $\begin{array}{l}\text { A2AR/A2BR } \\
\text { PD-1 } \\
\text { Chemotherapy }\end{array}$ & $\begin{array}{l}\text { AB928: } \\
\text { Dual A2AR and } \\
\text { A2BR Antagonist }\end{array}$ & Phase 1 & $\begin{array}{l}\text { Experimental: Dose Escalation Arm A, AB928 + Carboplatin + Pemetrexed } \\
\text { Experimental: Dose Escalation Arm B, AB928 + Carboplatin + Pemetrexed + } \\
\text { Pembrolizumab } \\
\text { Experimental: Dose Expansion Arm 1, recommended dose for expansion } \\
\text { ABg28 + Carboplatin + Pemetrexed in patients harboring sensitizing EGFR } \\
\text { mutation } \\
\text { Experimental: Dose Expansion Arm 2, recommended dose for expansion } \\
\text { ABg28 + Carboplatin + Pemetrexed + AB122 in patients harboring sensitizing } \\
\text { EGFR mutation }\end{array}$ & $\begin{array}{l}\text { Non-Small Cell Lung Cancer } \\
\text { Metastatic Non-Small Cell Lung } \\
\text { Cancer } \\
\text { Non-squamous Non-small Cell } \\
\text { Neoplasm of Lung Sensitizing } \\
\text { EGFR Gene Mutation }\end{array}$ & Recruiting & NCT03846310 \\
\hline A2BR & PBF-1129 & A2BR & PBF-1129: A2BR Antagonist & Phase 1 & $\begin{array}{l}\text { Experimental: PBF-1129_40 mg } \\
\text { Experimental: PBF-1129_80 mg } \\
\text { Experimental: PBF-1129_160 mg } \\
\text { Experimental: PBF-1129_320 mg }\end{array}$ & Non-Small Cell Lung Cancer & Recruiting & NCT03274479 \\
\hline
\end{tabular}


these trials were heavily pretreated ( $\geq 3$ prior treatments) (124). It will be interesting in the future to see if CD73 and/or A2AR therapy efficacy is increased further when used in earlier lines of therapy (124). Moreover, the authors discovered responding patients carry an AdenoSighi signature (124). Assessing whether this signature can also be detected in pretreatment biopsies of other cancers and possibly primary tumors may be beneficial (124). Biomarkers or gene signatures will likely be key in identifying patients benefiting the most from CD73/adenosine receptor therapy. Clinical trials are underway for $\mathrm{AB} 928$, a dual A2AR/A2BR antagonist, and include a focus on GI cancers [e.g., esophageal cancer and CRC; NCT03720678 (Table 3)]. A favorable safety profile of AB928 combined with chemotherapy has been reported in patients (252). Future studies in GI cancers that focus on determining if adenosine-mediated resistance to immunotherapy therapy exists at diagnosis or evolves with therapy will also be of significant benefit. Encouraging early results for BMS-986179 combined with nivolumab report clinical benefit (partial response) in one or more patients with pancreatic and prostate cancer (NCT02754141) (251). Both are poorly immunogenic tumors. Preclinical studies show CD73/adenosine therapy (e.g., A2AR deletion) liberates CD8+ $\mathrm{T}$ cells for antitumor activity even against weakly immunogenic sarcomas (70). Therapy benefit in these studies is independent of the anatomical location of the tumor (70). Thus, therapeutic benefit across many tumors (immunogenic and non-immunogenic) is expected. Understanding factors preventing immune cells from recognizing and eliminating cancer cells will continue to be important in the advancement of immunotherapy strategies. Poor tumor immunogenicity can be a result of many features, including HLA class I molecule downregulation or loss (253); genetic, epigenetic, and chromosome alterations regulating presentation and processing of surface epitopes (254-256); expression and secretion of immunosuppressive factors (e.g., PD-1, TGF- $\beta$, adenosine) (257); and the inability of cancer cells to produce new surface epitopes that are different from what immune receptors have regularly experienced (258). Whether CD73 expression associates with dMMR/MSI-H in GI tumors and its blockade would further increase immunotherapy efficacy in these tumors is unknown. In NSCLC studies, tumor mutational burden and neoantigen burden does not associate with CD73 high or low expression (74).

Taking advantage of strong associations of CD73 with molecular and genetic alterations (e.g., KRAS mutation and EGFR alterations) may benefit GI cancers. Combination studies of CD73 inhibitors with anti-EGFR therapy and/or tyrosine kinase inhibitors are in clinical trials for managing resistance (Table 3). In CRC, high CD73 predicts patients benefiting from cetuximab (anti-EGFR therapy) (234). Benefits are the same for both wild-type and mutant KRAS tumors (234). It would be interesting to see the performance of combination cetuximab with CD73 inhibitors in preclinical CRC studies considering that inflammation is a mechanism of resistance to cetuximab (259). In melanoma, combination BRAF and MEK inhibitors with an A2AR antagonist induces significant tumor control in preclinical studies (41). MEK is a promising target for KRAS, $N R A S$, and BRAF mutant tumors and is being targeted in CRC (260). Recently, MEK inhibitor, cobimetinib, combined with anti-PD-L1 therapy (atezolizumab) failed to improve survival in microsatellite-stable metastatic CRC patients in a phase 3 clinical trial (261). Could the inclusion of A2AR antagonists be key to the success of these studies? AMG510, a selective inhibitor for KRAS (G12C) recently showed promising antitumor effects, including increasing ICI therapy sensitivity in preclinical models (262). Its combination with CD73/adenosine receptor blockade may be a promising future approach. AMG510 is in clinical trials (NCT03600883). Mentioned previously, hyperoxia induces antitumor immunity in preclinical studies, which involves the downregulation of many adenosine pathway genes $(102,108)$. With drug toxicity being a concern with studies pushing past two targets, approaches like this that can simultaneously dampen multiple immune checkpoints may be better tolerated and provide greater benefit (263). Although a drawback of hyperoxia therapy is that it may/does cause tissue damage $(263,264)$, it is interesting to consider whether this response also benefits in helping to recover antitumor immunity. Hyperoxia is in clinical trials for many conditions/diseases (ClinicalTrials.gov; hyperoxia, 87 studies).

\section{CONCLUSIONS}

Immunotherapy in GI cancers currently benefits only a few patients. Blocking adenosine signaling by inhibiting CD73 and/or $\mathrm{A} 2 \mathrm{AR} / \mathrm{A} 2 \mathrm{BR}$ antagonism has the potential to improve antitumor immunity in these tumors. However, identifying which patients may benefit stands in the way. To aid in these efforts, a better understanding of CD73 in human GI cancers is greatly needed. This includes initiating studies that assess CD73 in addition to other ecto-enzymes involved in extracellular adenosine synthesis and metabolism as well as their association with key molecular and genetic features. A focus of CD73 expression in primary, pretreatment, and relapsed samples will also be of great value in addition to identifying predictive biomarkers or gene signatures relating to efficacy of CD73/adenosine receptor blockade. Mechanistically, studies assessing CD73/extracellular adenosine receptor activity in humanized and autochthonous tumor mouse models and patient-derived organoids will provide needed insight into the role of CD73/extracellular adenosine in these tumors. Moreover, studies in HCC have revealed CD73 overexpression in human tumors can be misleading. Future studies also incorporating this insight have the best chance of helping to better define CD73 in GI cancers.

\section{AUTHOR'S NOTE}

The figure was created using Servier Medical ART templates, which are licensed under a Creative Commons Attribution 3.0 Unported License; https://smart.servier.com. 


\section{AUTHOR CONTRIBUTIONS}

$\mathrm{JH}, \mathrm{LP}, \mathrm{OV}$, and JB drafted, edited, and
revised the manuscript figure.

\section{REFERENCES}

1. Magalhaes H, Fontes-Sousa M, Machado M. Immunotherapy in advanced gastric cancer: an overview of the emerging strategies. Can J Gastroenterol Hepatol. (2018) 2018:2732408. doi: 10.1155/2018/2732408

2. Villanueva A. Hepatocellular carcinoma. N Engl J Med. (2019) 380:145062. doi: 10.1056/NEJMra1713263

3. Siegel RL, Miller KD, Jemal A. Cancer statistics, 2017. CA Cancer J Clin. (2017) 67:7-30. doi: 10.3322/caac.21387

4. Rahib L, Smith BD, Aizenberg R, Rosenzweig AB, Fleshman JM, Matrisian LM. Projecting cancer incidence and deaths to 2030: the unexpected burden of thyroid, liver, and pancreas cancers in the United States. Cancer Res. (2014) 74:2913-21. doi: 10.1158/0008-5472.CAN-14-0155

5. Bray F, Ferlay J, Soerjomataram I, Siegel RL, Torre LA, Jemal A. Global cancer statistics 2018: GLOBOCAN estimates of incidence and mortality worldwide for 36 cancers in 185 countries. CA Cancer J Clin. (2018) 68:394424. doi: 10.3322/caac. 21492

6. Bang YJ, Kang YK, Catenacci DV, Muro K, Fuchs CS, Geva R, et al. Pembrolizumab alone or in combination with chemotherapy as first-line therapy for patients with advanced gastric or gastroesophageal junction adenocarcinoma: results from the phase II nonrandomized KEYNOTE-059 study. Gastric Cancer. (2019) 22:828-37. doi: 10.1007/s10120-018-00909-5

7. Zhu AX, Finn RS, Edeline J, Cattan S, Ogasawara S, Palmer D, et al. Pembrolizumab in patients with advanced hepatocellular carcinoma previously treated with sorafenib (KEYNOTE-224): a non-randomised, open-label phase 2 trial. Lancet Oncol. (2018) 19:940-52. doi: 10.1200/JCO.2018.36.4_suppl.209

8. Le DT, Uram JN, Wang H, Bartlett BR, Kemberling H, Eyring AD, et al. PD1 blockade in tumors with mismatch-repair deficiency. N Engl J Med. (2015) 372:2509-20. doi: 10.1056/NEJMoa1500596

9. El-Khoueiry AB, Sangro B, Yau T, Crocenzi TS, Kudo M, Hsu $\mathrm{C}$, et al. Nivolumab in patients with advanced hepatocellular carcinoma (CheckMate 040): an open-label, non-comparative, phase $1 / 2$ dose escalation and expansion trial. Lancet. (2017) 389:2492-502. doi: 10.1016/S0140-6736(17)31046-2

10. Overman MJ, McDermott R, Leach JL, Lonardi S, Lenz HJ, Morse MA, et al. Nivolumab in patients with metastatic DNA mismatch repair-deficient or microsatellite instability-high colorectal cancer (CheckMate 142): an open-label, multicentre, phase 2 study. Lancet Oncol. (2017) 18:118291. doi: 10.1016/S1470-2045(17)30422-9

11. Overman MJ, Lonardi S, Wong KYM, Lenz HJ, Gelsomino F, Aglietta M, et al. Durable clinical benefit with nivolumab plus ipilimumab in DNA mismatch repair-deficient/microsatellite instability-high metastatic colorectal cancer. $J$ Clin Oncol. (2018) 36:773-9. doi: 10.1200/JCO.2017.76.9901

12. Hazama S, Tamada K, Yamaguchi Y, Kawakami Y, Nagano H. Current status of immunotherapy against gastrointestinal cancers and its biomarkers: perspective for precision immunotherapy. Ann Gastroenterol Surg. (2018) 2:289-303. doi: 10.1002/ags3.12180

13. Le DT, Durham JN, Smith KN, Wang H, Bartlett BR, Aulakh LK, et al. Mismatch repair deficiency predicts response of solid tumors to PD-1 blockade. Science. (2017) 357:409-13. doi: 10.1126/science. aan 6733

14. Cicek MS, Lindor NM, Gallinger S, Bapat B, Hopper JL, Jenkins MA, et al. Quality assessment and correlation of microsatellite instability and immunohistochemical markers among population- and clinic-based colorectal tumors results from the Colon Cancer Family Registry. J Mol Diagn. (2011) 13:271-81. doi: 10.1016/j.jmoldx.2010.12.004

\section{FUNDING}

JB is supported by an International Research Society Mentored Research Award. LP was funded by a McGovern Medical School at UTHealth Dean's Office Stipend Award.

15. Zhao P, Li L, Jiang X, Li Q. Mismatch repair deficiency/microsatellite instability-high as a predictor for anti-PD-1/PD-L1 immunotherapy efficacy. J Hematol Oncol. (2019) 12:54. doi: 10.1186/s13045-019-0738-1

16. McGranahan N, Furness AJ, Rosenthal R, Ramskov S, Lyngaa R, Saini SK, et al. Clonal neoantigens elicit $\mathrm{T}$ cell immunoreactivity and sensitivity to immune checkpoint blockade. Science. (2016) 351:1463-9. doi: 10.1126/science.aaf1490

17. Rizvi NA, Hellmann MD, Snyder A, Kvistborg P, Makarov V, Havel JJ, et al. Cancer immunology. Mutational landscape determines sensitivity to PD-1 blockade in non-small cell lung cancer. Science. (2015) 348:124-8. doi: $10.1126 /$ science.aaa1348

18. Castle JC, Kreiter S, Diekmann J, Lower M, van de Roemer N, de Graaf J, et al. Exploiting the mutanome for tumor vaccination. Cancer Res. (2012) 72:1081-91. doi: 10.1158/0008-5472.CAN-11-3722

19. Dolcetti R, Viel A, Doglioni C, Russo A, Guidoboni M, Capozzi $\mathrm{E}$, et al. High prevalence of activated intraepithelial cytotoxic $\mathrm{T}$ lymphocytes and increased neoplastic cell apoptosis in colorectal carcinomas with microsatellite instability. Am J Pathol. (1999) 154:1805-13. doi: 10.1016/S0002-9440(10)65436-3

20. Guidoboni M, Gafa R, Viel A, Doglioni C, Russo A, Santini A, et al. Microsatellite instability and high content of activated cytotoxic lymphocytes identify colon cancer patients with a favorable prognosis. Am J Pathol. (2001) 159:297-304. doi: 10.1016/S0002-9440(10)61695-1

21. Hause RJ, Pritchard CC, Shendure J, Salipante SJ. Classification and characterization of microsatellite instability across 18 cancer types. Nat Med. (2016) 22:1342-50. doi: 10.1038/nm.4191

22. Kim JY, Shin NR, Kim A, Lee HJ, Park WY, Kim JY, et al. Microsatellite instability status in gastric cancer: a reappraisal of its clinical significance and relationship with mucin phenotypes. Korean J Pathol. (2013) 47:2835. doi: 10.4132/KoreanJPathol.2013.47.1.28

23. Cancer Genome Atlas Research Network. Comprehensive molecular characterization of gastric adenocarcinoma. Nature. (2014) 513:2029. doi: $10.1038 /$ nature 13480

24. Cancer Genome Atlas Research Network. Integrated genomic characterization of pancreatic ductal adenocarcinoma. Cancer Cell. (2017) 32:185-203 e13.

25. Cortes-Ciriano I, Lee S, Park WY, Kim TM, Park PJ. A molecular portrait of microsatellite instability across multiple cancers. Nat Commun. (2017) 8:15180. doi: $10.1038 /$ ncomms 15180

26. Goumard C, Desbois-Mouthon C, Wendum D, Calmel C, Merabtene F, Scatton $\mathrm{O}$, et al. Low levels of microsatellite instability at simple repeated sequences commonly occur in human hepatocellular carcinoma. Cancer Genomics Proteomics. (2017) 14:329-39. doi: 10.21873/cgp. 20043

27. Meinel S, Blohberger J, Berg D, Berg U, Dissen GA, Ojeda SR, et al. Pro-nerve growth factor in the ovary and human granulosa cells. Horm Mol Biol Clin Investig. (2015) 24:91-9. doi: 10.1515/hmbci-2015-0028

28. Procaccio L, Schirripa M, Fassan M, Vecchione L, Bergamo F, Prete AA, et al. Immunotherapy in gastrointestinal cancers. Biomed Res Int. (2017) 2017:4346576. doi: 10.1155/2017/4346576

29. Sambi M, Bagheri L, Szewczuk MR. Current challenges in cancer immunotherapy: multimodal approaches to improve efficacy, and patient response rates. J Oncol. (2019) 2019:4508794. doi: 10.1155/2019/4508794

30. Jin D, Fan J, Wang L, Thompson LF, Liu A, Daniel BJ, et al. CD73 on tumor cells impairs antitumor T-cell responses: a novel mechanism of tumor-induced immune suppression. Cancer Res. (2010) 70:224555. doi: 10.1158/0008-5472.CAN-09-3109 
31. Stagg J, Divisekera U, McLaughlin N, Sharkey J, Pommey S, Denoyer D, et al. Anti-CD73 antibody therapy inhibits breast tumor growth and metastasis. Proc Natl Acad Sci USA. (2010) 107:1547-52. doi: 10.1073/pnas.0908801107

32. Stagg J, Divisekera U, Duret H, Sparwasser T, Teng MW, Darcy PK, et al. CD73-deficient mice have increased antitumor immunity and are resistant to experimental metastasis. Cancer Res. (2011) 71:2892900. doi: 10.1158/0008-5472.CAN-10-4246

33. Wang L, Fan J, Thompson LF, Zhang Y, Shin T, Curiel TJ, et al. CD73 has distinct roles in nonhematopoietic and hematopoietic cells to promote tumor growth in mice. J Clin Invest. (2011) 121:2371-82. doi: 10.1172/ JCI45559

34. Yegutkin GG, Marttila-Ichihara F, Karikoski M, Niemela J, Laurila JP, Elima $\mathrm{K}$, et al. Altered purinergic signaling in CD73-deficient mice inhibits tumor progression. Eur J Immunol. (2011) 41:1231-41. doi: 10.1002/eji.201041292

35. Stagg J, Beavis PA, Divisekera U, Liu MC, Moller A, Darcy PK, et al. CD73deficient mice are resistant to carcinogenesis. Cancer Res. (2012) 72:21906. doi: 10.1158/0008-5472.CAN-12-0420

36. Loi S, Pommey S, Haibe-Kains B, Beavis PA, Darcy PK, Smyth MJ, et al. CD73 promotes anthracycline resistance and poor prognosis in triple negative breast cancer. Proc Natl Acad Sci USA. (2013) 110:110916. doi: $10.1073 /$ pnas. 1222251110

37. Allard B, Pommey S, Smyth MJ, Stagg J. Targeting CD73 enhances the antitumor activity of anti-PD-1 and anti-CTLA-4 mAbs. Clin Cancer Res. (2013) 19:5626-35. doi: 10.1158/1078-0432.CCR-13-0545

38. Beavis PA, Divisekera U, Paget C, Chow MT, John LB, Devaud $\mathrm{C}$, et al. Blockade of A2A receptors potently suppresses the metastasis of CD73+ tumors. Proc Natl Acad Sci USA. (2013) 110:14711-6. doi: 10.1073/pnas.1308209110

39. Young A, Ngiow SF, Barkauskas DS, Sult E, Hay C, Blake SJ, et al. Co-inhibition of CD73, and A2AR adenosine signaling improves anti-tumor immune responses. Cancer Cell. (2016) 30:391-403. doi: 10.1016/j.ccell.2016.06.025

40. Hay CM, Sult E, Huang Q, Mulgrew K, Fuhrmann SR, McGlinchey KA, et al. Targeting CD73 in the tumor microenvironment with MEDI9447. Oncoimmunology. (2016) 5:e1208875. doi: 10.1080/2162402X.2016.1208875

41. Reinhardt J, Landsberg J, Schmid-Burgk JL, Ramis BB, Bald T, Glodde $\mathrm{N}$, et al. MAPK signaling, and inflammation link melanoma phenotype switching to induction of CD73 during immunotherapy. Cancer Res. (2017) 77:4697-709. doi: 10.1158/0008-5472.CAN-17-0395

42. Young A, Ngiow SF, Madore J, Reinhardt J, Landsberg J, Chitsazan A, et al. Targeting adenosine in BRAF-mutant melanoma reduces tumor growth, and metastasis. Cancer Res. (2017) 77:4684-96. doi: 10.1158/0008-5472.CAN-17-0393

43. Iannone R, Miele L, Maiolino P, Pinto A, Morello S. Adenosine limits the therapeutic effectiveness of anti-CTLA4 $\mathrm{mAb}$ in a mouse melanoma model. Am J Cancer Res. (2014) 4:172-81. eCollection 2014.

44. Perrot I, Michaud HA, Giraudon-Paoli M, Augier S, Docquier A, Gros L, et al. Blocking antibodies targeting the CD39/CD73 immunosuppressive pathway unleash immune responses in combination cancer therapies. Cell Rep. (2019) 27:2411-25 e9. doi: 10.1016/j.celrep.2019.04.091

45. Linden J, Koch-Nolte F, Dahl G. Purine release, metabolism, and signaling in the inflammatory response. Annu Rev Immunol. (2019) 37:32547. doi: 10.1146/annurev-immunol-051116-052406

46. Bowser JL, Lee JW, Yuan X, Eltzschig HK. The hypoxiaadenosine link during inflammation. J Appl Physiol. (2017) 123:1303-20. doi: 10.1152/japplphysiol.00101.2017

47. Bowser JL, Phan LH, Eltzschig HK. The hypoxia-adenosine link during intestinal inflammation. J Immunol. (2018) 200:897907. doi: 10.4049/jimmunol.1701414

48. Robeva AS, Woodard RL, Jin X, Gao Z, Bhattacharya S, Taylor HE, et al. Molecular characterization of recombinant human adenosine receptors. Drug Dev Res. (1996) 39:243-52. doi: 10.1002/(SICI)1098-2299(199611/ 12)39:3/4<243::AID-DDR3>3.0.CO;2-R

49. Cronstein BN, Naime D, Ostad E. The antiinflammatory mechanism of methotrexate. Increased adenosine release at inflamed sites diminishes leukocyte accumulation in an in vivo model of inflammation. J Clin Invest. (1993) 92:2675-82. doi: 10.1172/JCI116884
50. Ohta A, Sitkovsky M. Role of G-protein-coupled adenosine receptors in downregulation of inflammation and protection from tissue damage. Nature. (2001) 414:916-20. doi: 10.1038/414916a

51. Kohler D, Eckle T, Faigle M, Grenz A, Mittelbronn M, Laucher S, et al. CD39/ectonucleoside triphosphate diphosphohydrolase 1 provides myocardial protection during cardiac ischemia/reperfusion injury. Circulation. (2007) 116:178494. doi: 10.1161/CIRCULATIONAHA.107.690180

52. Yang Z, Day YJ, Toufektsian MC, Ramos SI, Marshall M, Wang XQ, et al. Infarct-sparing effect of A2A-adenosine receptor activation is due primarily to its action on lymphocytes. Circulation. (2005) 111:21907. doi: 10.1161/01.CIR.0000163586.62253.A5

53. Rose JB, Naydenova Z, Bang A, Eguchi M, Sweeney G, Choi DS, et al. Equilibrative nucleoside transporter 1 plays an essential role in cardioprotection. Am J Physiol Heart Circ Physiol. (2010) 298:H7717. doi: $10.1152 /$ ajpheart.00711.2009

54. Eckle T, Fullbier L, Wehrmann M, Khoury J, Mittelbronn M, Ibla J, et al. Identification of ectonucleotidases CD39, and CD73 in innate protection during acute lung injury. J Immunol. (2007) 178:812737. doi: 10.4049/jimmunol.178.12.8127

55. Eckle T, Grenz A, Laucher S, Eltzschig HK. A2B adenosine receptor signaling attenuates acute lung injury by enhancing alveolar fluid clearance in mice. $J$ Clin Invest. (2008) 118:3301-15. doi: 10.1172/JCI34203

56. Eckle T, Hughes K, Ehrentraut H, Brodsky KS, Rosenberger P, Choi DS, et al. Crosstalk between the equilibrative nucleoside transporter ENT2 and alveolar Adora2b adenosine receptors dampens acute lung injury. FASEB J. (2013) 27:3078-89. doi: 10.1096/fj.13-228551

57. Eckle T, Kewley EM, Brodsky KS, Tak E, Bonney S, Gobel M, et al. Identification of hypoxia-inducible factor HIF-1A as transcriptional regulator of the $\mathrm{A} 2 \mathrm{~B}$ adenosine receptor during acute lung injury. J Immunol. (2014) 192:1249-56. doi: 10.4049/jimmunol.1100593

58. Schingnitz U, Hartmann K, Macmanus CF, Eckle T, Zug S, Colgan $\mathrm{SP}$, et al. Signaling through the A2B adenosine receptor dampens endotoxin-induced acute lung injury. J Immunol. (2010) 184:52719. doi: 10.4049/jimmunol.0903035

59. Hart ML, Jacobi B, Schittenhelm J, Henn M, Eltzschig HK. Cutting edge: $\mathrm{A} 2 \mathrm{~B}$ adenosine receptor signaling provides potent protection during intestinal ischemia/reperfusion injury. J Immunol. (2009) 182:39658. doi: 10.4049/jimmunol.0802193

60. Taha MO, Miranda-Ferreira R, Simoes RS, Abrao MS, Oliveira-Junior IS, Monteiro HP, et al. Caricati-neto: role of adenosine on intestinal ischemia-reperfusion injury in rabbits. Transplant Proc. (2010) 42:4546. doi: 10.1016/j.transproceed.2010.01.019

61. Haddad MA, Miranda-Ferreira R, Taha NS, Maldonado VC, Daroz RR, Daud MO, et al. Effect of adenosine on injury caused by ischemia and reperfusion in rats: functional and morphologic study. Transplant Proc. (2012) 44:2317-20. doi: 10.1016/j.transproceed.2012.07.057

62. Friedman DJ, Kunzli BM, A-Rahim YI, Sevigny J, Berberat PO, Enjyoji $\mathrm{K}$, et al. From the cover: CD39 deletion exacerbates experimental murine colitis and human polymorphisms increase susceptibility to inflammatory bowel disease. Proc Natl Acad Sci USA. (2009) 106:1678893. doi: 10.1073/pnas.0902869106

63. Louis NA, Robinson AM, MacManus CF, Karhausen J, Scully M, Colgan SP. Control of IFN-alphaA by CD73: implications for mucosal inflammation. J Immunol. (2008) 180:4246-55. doi: 10.4049/jimmunol.180. 6.4246

64. Aherne CM, Saeedi B, Collins CB, Masterson JC, McNamee EN, Perrenoud $\mathrm{L}$, et al. Epithelial-specific A2B adenosine receptor signaling protects the colonic epithelial barrier during acute colitis. Mucosal Immunol. (2015) 8:1324-38. doi: 10.1038/mi.2015.22

65. Aherne CM, Collins CB, Rapp CR, Olli KE, Perrenoud L, Jedlicka $\mathrm{P}$, et al. Coordination of ENT2-dependent adenosine transport and signaling dampens mucosal inflammation. JCI Insight. (2018) 3. doi: $10.1172 /$ jci.insight. 121521

66. Blay J, White TD, Hoskin DW. The extracellular fluid of solid carcinomas contains immunosuppressive concentrations of adenosine. Cancer Res. (1997) 57:2602-5. 
67. Ohta A, Gorelik E, Prasad SJ, Ronchese F, Lukashev D, Wong MK, et al. A2A adenosine receptor protects tumors from antitumor T cells. Proc Natl Acad Sci USA. (2006) 103:13132-7. doi: 10.1073/pnas.0605251103

68. Willingham SB, Ho PY, Hotson A, Hill C, Piccione EC, Hsieh J, et al. A2AR Antagonism with CPI-444 induces antitumor responses, and augments efficacy to Anti-PD-(L)1, and Anti-CTLA-4 in preclinical models. Cancer Immunol Res. (2018) 6:1136-49. doi: 10.1158/2326-6066.CIR-18-0056

69. Leone RD, Sun IM, Oh MH, Sun IH, Wen J, Englert J, et al. Inhibition of the adenosine A2a receptor modulates expression of $\mathrm{T}$ cell coinhibitory receptors and improves effector function for enhanced checkpoint blockade, and ACT in murine cancer models. Cancer Immunol Immunother. (2018) 67:1271-84. doi: 10.1007/s00262-018-2186-0

70. Kjaergaard J, Hatfield S, Jones G, Ohta A, Sitkovsky M. A2A adenosine receptor gene deletion or synthetic $\mathrm{A} 2 \mathrm{~A}$ antagonist liberate tumor-reactive CD8(+) T cells from tumor-induced immunosuppression. J Immunol. (2018) 201:782-91. doi: 10.4049/jimmunol.1700850

71. Yan A, Joachims ML, Thompson LF, Miller AD, Canoll PD, Bynoe MS. CD73 promotes glioblastoma pathogenesis, and enhances its chemoresistance via A2B adenosine receptor signaling. J Neurosci. (2019) 39:4387402. doi: 10.1523/JNEUROSCI.1118-18.2019

72. Allard B, Turcotte M, Spring K, Pommey S, Royal I, Stagg J. AntiCD73 therapy impairs tumor angiogenesis. Int J Cancer. (2014) 134:146673. doi: $10.1002 / \mathrm{ijc} .28456$

73. Buisseret L, Pommey S, Allard B, Garaud S, Bergeron M, Cousineau I, et al. Clinical significance of CD73 in triple-negative breast cancer: multiplex analysis of a phase III clinical trial. Ann Oncol. (2018) 29:105662. doi: 10.1093/annonc/mdx730

74. Park LC, Rhee K, Kim WB, Cho A, Song J, Anker JF, et al. Immunologic and clinical implications of CD73 expression in non-small cell lung cancer (NSCLC) J Clin Oncol. (2018) 36(15_suppl):12050. doi: 10.1200/JCO.2018.36.15_suppl.12050

75. Lu XX, Chen YT, Feng B, Mao XB, Yu B, Chu XY. Expression and clinical significance of $\mathrm{CD} 73$ and hypoxia-inducible factorlalpha in gastric carcinoma. World J Gastroenterol. (2013) 19:1912-8. doi: 10.3748/wjg.v19.i12.1912

76. Turcotte M, Spring K, Pommey S, Chouinard G, Cousineau I, George J, et al. CD73 is associated with poor prognosis in high-grade serous ovarian cancer. Cancer Res. (2015) 75:4494-503. doi: 10.1158/0008-5472.CAN-14-3569

77. Zhou L, Jia S, Chen Y, Wang W, Wu Z, Yu W, et al. The distinct role of CD73 in the progression of pancreatic cancer. J Mol Med. (2019) 97:80315. doi: 10.1007/s00109-018-01742-0

78. Wu XR, He XS, Chen YF, Yuan RX, Zeng Y, Lian L, et al. High expression of CD73 as a poor prognostic biomarker in human colorectal cancer. J Surg Oncol. (2012) 106:130-7. doi: 10.1002/jso.23056

79. Lupia M, Angiolini F, Bertalot G, Freddi S, Sachsenmeier KF, Chisci $\mathrm{E}$, et al. CD73 regulates stemness, and epithelial-mesenchymal transition in ovarian cancer-initiating cells. Stem Cell Rep. (2018) 10:1412-25. doi: 10.1016/j.stemcr.2018.02.009

80. Katsuta E, Tanaka S, Mogushi K, Shimada S, Akiyama Y, Aihara A, et al. CD73 as a therapeutic target for pancreatic neuroendocrine tumor stem cells. Int J Oncol. (2016) 48:657-69. doi: 10.3892/ijo.2015.3299

81. Turcotte M, Allard D, Mittal D, Bareche Y, Buisseret L, Jose V, et al. CD73 promotes resistance to HER2/ErbB2 antibody therapy. Cancer Res. (2017) 77:5652-63. doi: 10.1158/0008-5472.CAN-17-0707

82. Ujhazy P, Berleth ES, Pietkiewicz JM, Kitano H, Skaar JR, Ehrke MJ, et al. Evidence for the involvement of ecto-5' -nucleotidase (CD73) in drug resistance. Int J Cancer. (1996) 68:493-500.

83. Bavaresco L, Bernardi A, Braganhol E, Cappellari AR, Rockenbach L, Farias PF, et al. The role of ecto-5'-nucleotidase/CD73 in glioma cell line proliferation. Mol Cell Biochem. (2008) 319:61-8. doi: 10.1007/s11010-008-9877-3

84. Xiong L, Wen Y, Miao X, Yang Z. NT5E, and FcGBP as key regulators of TGF-1-induced epithelial-mesenchymal transition (EMT) are associated with tumor progression and survival of patients with gallbladder cancer. Cell Tissue Res. (2014) 355:365-74. doi: 10.1007/s00441-013-1752-1

85. Ryzhov S, Novitskiy SV, Zaynagetdinov R, Goldstein AE, Carbone DP, Biaggioni I, et al. Host $\mathrm{A}(2 \mathrm{~B})$ adenosine receptors promote carcinoma growth. Neoplasia. (2008) 10:987-95. doi: 10.1593/neo.08478
86. Cekic C, Sag D, Li Y, Theodorescu D, Strieter RM, Linden J. Adenosine A2B receptor blockade slows growth of bladder and breast tumors. J Immunol. (2012) 188:198-205. doi: 10.4049/jimmunol.1101845

87. Iannone R, Miele L, Maiolino P, Pinto A, Morello S. Blockade of $\mathrm{A} 2 \mathrm{~b}$ adenosine receptor reduces tumor growth and immune suppression mediated by myeloid-derived suppressor cells in a mouse model of melanoma. Neoplasia. (2013) 15:1400-9. doi: 10.1593/neo. 131748

88. Huang S, Apasov S, Koshiba M, Sitkovsky M. Role of A2a extracellular adenosine receptor-mediated signaling in adenosinemediated inhibition of T-cell activation and expansion. Blood. (1997) 90:1600-10. doi: 10.1182/blood.V90.4.1600.1600_1600_1610

89. Ohta A, Ohta A, Madasu M, Kini R, Subramanian M, Goel N, et al. $\mathrm{A} 2 \mathrm{~A}$ adenosine receptor may allow expansion of $\mathrm{T}$ cells lacking effector functions in extracellular adenosine-rich microenvironments. J Immunol. (2009) 183:5487-93. doi: 10.4049/jimmunol.0901247

90. Lappas CM, Rieger JM, Linden J. A2A adenosine receptor induction inhibits IFN-gamma production in murine CD4+ T cells. J Immunol. (2005) 174:1073-80. doi: 10.4049/jimmunol.174.2.1073

91. Ohta A, Kini R, Ohta A, Subramanian M, Madasu M, Sitkovsky M. The development and immunosuppressive functions of CD4(+) $\mathrm{CD} 25(+)$ FoxP3(+) regulatory $\mathrm{T}$ cells are under influence of the adenosine-A2A adenosine receptor pathway. Front Immunol. (2012) 3:190. doi: 10.3389/fimmu.2012.00190

92. Deaglio S, Dwyer KM, Gao W, Friedman D, Usheva A, Erat A, et al. Adenosine generation catalyzed by CD39, and CD73 expressed on regulatory $\mathrm{T}$ cells mediates immune suppression. J Exp Med. (2007) 204:125765. doi: 10.1084/jem.20062512

93. Mandapathil M, Hilldorfer B, Szczepanski MJ, Czystowska M, Szajnik M, Ren J, et al. Generation and accumulation of immunosuppressive adenosine by human CD4+CD25highFOXP3+ regulatory T cells. J Biol Chem. (2010) 285:7176-86. doi: 10.1074/jbc.M109.047423

94. Burton CT, Westrop SJ, Eccles-James I, Boasso A, Nelson MR, Bower M, et al. Altered phenotype of regulatory $\mathrm{T}$ cells associated with lack of human immunodeficiency virus (HIV)-1-specific suppressive function. Clin Exp Immunol. (2011) 166:191-200. doi: 10.1111/j.1365-2249.2011.04451.x

95. Borsellino G, Kleinewietfeld M, Di Mitri D, Sternjak A, Diamantini A, Giometto R, et al. Expression of ectonucleotidase CD39 by Foxp3+ Treg cells: hydrolysis of extracellular ATP and immune suppression. Blood. (2007) 110:1225-32. doi: 10.1182/blood-2006-12-064527

96. Allard B, Longhi MS, Robson SC, Stagg J. The ectonucleotidases CD39, and CD73: novel checkpoint inhibitor targets. Immunol Rev. (2017) 276:12144. doi: 10.1111/imr.12528

97. Clayton A, Al-Taei S, Webber J, Mason MD, Tabi Z. Cancer exosomes express CD39, and CD73, which suppress $\mathrm{T}$ cells through adenosine production. J Immunol. (2011) 187:676-83. doi: 10.4049/jimmunol.100 3884

98. Morandi F, Marimpietri D, Horenstein AL, Bolzoni M, Toscani D, Costa F, et al. Microvesicles released from multiple myeloma cells are equipped with ectoenzymes belonging to canonical and non-canonical adenosinergic pathways and produce adenosine from ATP, and NAD. Oncoimmunology. (2018) 7:e1458809. doi: 10.1080/2162402X.2018.1458809

99. Duhen T, Duhen R, Montler R, Moses J, Moudgil T, de Miranda $\mathrm{NF}$, et al. Co-expression of CD39, and CD103 identifies tumorreactive CD8 T cells in human solid tumors. Nat Commun. (2018) 9:2724. doi: 10.1038/s41467-018-05072-0

100. Zarek PE, Huang CT, Lutz ER, Kowalski J, Horton MR, Linden J, et al. A2A receptor signaling promotes peripheral tolerance by inducing T-cell anergy and the generation of adaptive regulatory T cells. Blood. (2008) 111:251-9. doi: 10.1182/blood-2007-03-081646

101. Young A, Ngiow SF, Gao Y, Patch AM, Barkauskas DS, Messaoudene $M$, et al. A2AR adenosine signaling suppresses natural killer cell maturation in the tumor microenvironment. Cancer Res. (2018) 78:100316. doi: 10.1158/0008-5472.CAN-17-2826

102. Hatfield SM, Kjaergaard J, Lukashev D, Schreiber TH, Belikoff $\mathrm{B}$, Abbott R, et al. Immunological mechanisms of the antitumor effects of supplemental oxygenation. Sci Transl Med. (2015) 7:277ra30. doi: $10.1126 /$ scitranslmed.aaa1260 
103. Miller JS, Cervenka T, Lund J, Okazaki IJ, Moss J. Purine metabolites suppress proliferation of human NK cells through a lineage-specific purine receptor. $J$ Immunol. (1999) 162:7376-82.

104. Lokshin A, Raskovalova T, Huang X, Zacharia LC, Jackson EK, Gorelik E. Adenosine-mediated inhibition of the cytotoxic activity and cytokine production by activated natural killer cells. Cancer Res. (2006) 66:775865. doi: 10.1158/0008-5472.CAN-06-0478

105. Priebe T, Platsoucas CD, Nelson JA. Adenosine receptors and modulation of natural killer cell activity by purine nucleosides. Cancer Res. (1990) 50:4328-31.

106. Williams BA, Manzer A, Blay J, Hoskin DW. Adenosine acts through a novel extracellular receptor to inhibit granule exocytosis by natural killer cells. Biochem Biophys Res Commun. (1997) 231:264-9. doi: 10.1006/bbrc. 1997.6077

107. Raskovalova T, Huang X, Sitkovsky M, Zacharia LC, Jackson EK, Gorelik E. Gs protein-coupled adenosine receptor signaling and lytic function of activated NK cells. J Immunol. (2005) 175:4383-91. doi: 10.4049/jimmunol.175.7.4383

108. Hatfield SM, Kjaergaard J, Lukashev D, Belikoff B, Schreiber $\mathrm{TH}$, Sethumadhavan S, et al. Systemic oxygenation weakens the hypoxia and hypoxia inducible factor lalpha-dependent and extracellular adenosine-mediated tumor protection. J Mol Med. (2014) 92:1283-92. doi: 10.1007/s00109-014-1189-3

109. Synnestvedt K, Furuta GT, Comerford KM, Louis N, Karhausen J, Eltzschig $\mathrm{HK}$, et al. Ecto-5'-nucleotidase (CD73) regulation by hypoxia-inducible factor-1 mediates permeability changes in intestinal epithelia. J Clin Invest. (2002) 110:993-1002. doi: 10.1172/JCI0215337

110. Ahmad A, Ahmad S, Glover L, Miller SM, Shannon JM, Guo X, et al. Adenosine A2A receptor is a unique angiogenic target of HIF-2alpha in pulmonary endothelial cells. Proc Natl Acad Sci USA. (2009) 106:106849. doi: 10.1073/pnas. 0901326106

111. Kong T, Westerman KA, Faigle M, Eltzschig HK, Colgan SP. HIF-dependent induction of adenosine A2B receptor in hypoxia. FASEB J. (2006) 20:224250. doi: 10.1096/fj.06-6419com

112. Neo SY, Yang Y, Julien R, Ma R, Chen X, Chen Z, et al. CD73 immune checkpoint defines regulatory NK-cells within the tumor microenvironment. J Clin Invest. (2020) 130:1185-98. doi: 10.1172/JCI128895

113. Li J, Wang L, Chen X, Li L, Li Y, Ping Y, et al. CD39/CD73 upregulation on myeloid-derived suppressor cells via TGF-beta-mTOR-HIF-1 signaling in patients with non-small cell lung cancer. Oncoimmunology. (2017) 6:e1320011. doi: 10.1080/2162402X.2017.1320011

114. Limagne E, Euvrard R, Thibaudin M, Rebe C, Derangere V, Chevriaux A, et al. Accumulation of MDSC, and Th17 cells in patients with metastatic colorectal cancer predicts the efficacy of a FOLFOX-bevacizumab drug treatment regimen. Cancer Res. (2016) 76:5241-52. doi: 10.1158/0008-5472.CAN-15-3164

115. Ryzhov S, Novitskiy SV, Goldstein AE, Biktasova A, Blackburn MR, Biaggioni I, et al. Adenosinergic regulation of the expansion and immunosuppressive activity of CD11b+Gr1+ cells. J Immunol. (2011) 187:6120-9. doi: 10.4049/jimmunol.1101225

116. Montalban Del Barrio Penski C, Schlahsa L, Stein RG, Diessner J, Wockel A, Dietl J, et al. Adenosine-generating ovarian cancer cells attract myeloid cells which differentiate into adenosine-generating tumor associated macrophages - a self-amplifying, CD39-, and CD73-dependent mechanism for tumor immune escape. I Immunother Cancer. (2016) 4:49. doi: 10.1186/s40425-016-0154-9

117. Hofer S, Ivarsson L, Stoitzner P, Auffinger M, Rainer C, Romani N, et al. Adenosine slows migration of dendritic cells but does not affect other aspects of dendritic cell maturation. J Invest Dermatol. (2003) 121:3007. doi: 10.1046/j.1523-1747.2003.12369.x

118. Novitskiy SV, Ryzhov S, Zaynagetdinov R, Goldstein AE, Huang $\mathrm{Y}$, Tikhomirov OY, et al. Adenosine receptors in regulation of dendritic cell differentiation and function. Blood. (2008) 112:1822-31. doi: 10.1182/blood-2008-02-136325

119. Challier J, Bruniquel D, Sewell AK, Laugel B. Adenosine and cAMP signalling skew human dendritic cell differentiation towards a tolerogenic phenotype with defective CD8(+) T-cell priming capacity. Immunology. (2013) 138:402-10. doi: 10.1111/imm.12053
120. Panther E, Corinti S, Idzko M, Herouy Y, Napp M, la Sala A, et al. Adenosine affects expression of membrane molecules, cytokine and chemokine release, and the T-cell stimulatory capacity of human dendritic cells. Blood. (2003) 101:3985-90. doi: 10.1182/blood-200207-2113

121. Wilson JM, Kurtz CC, Black SG, Ross WG, Alam MS, Linden J, et al. The A2B adenosine receptor promotes Th17 differentiation via stimulation of dendritic cell IL-6. J Immunol. (2011) 186:674652. doi: 10.4049/jimmunol.1100117

122. Mittal D, Young A, Stannard K, Yong M, Teng MW, Allard B, et al. Antimetastatic effects of blocking PD-1 and the adenosine A2A receptor. Cancer Res. (2014) 74:3652-8. doi: 10.1158/0008-5472.CAN-14-0957

123. Beavis PA, Milenkovski N, Henderson MA, John LB, Allard B, Loi S, et al. Adenosine receptor $2 \mathrm{~A}$ blockade increases the efficacy of Anti-PD-1 through enhanced antitumor T-cell responses. Cancer Immunol Res. (2015) 3:50617. doi: 10.1158/2326-6066.CIR-14-0211

124. Fong L, Hotson A, Powderly JD, Sznol M, Heist RS, Choueiri TK, et al. Adenosine 2A receptor blockade as an immunotherapy for treatment-refractory renal cell cancer. Cancer Discov. (2020) 10:4053. doi: 10.1158/2159-8290.CD-19-0980

125. Chen S, Fan J, Zhang M, Qin L, Dominguez D, Long A, et al. CD73 expression on effector $\mathrm{T}$ cells sustained by TGF-beta facilitates tumor resistance to anti-4-1BB/CD137 therapy. Nat Commun. (2019) 10:150. doi: 10.1038/s41467-018-08123-8

126. Melero I, Johnston JV, Shufford WW, Mittler RS, Chen L. NK1.1 cells express 4-1BB (CDw137) costimulatory molecule and are required for tumor immunity elicited by anti-4-1BB monoclonal antibodies. Cell Immunol. (1998) 190:167-72. doi: 10.1006/cimm.1998.1396

127. Shuford WW, Klussman K, Tritchler DD, Loo DT, Chalupny J, Siadak $\mathrm{AW}$, et al. $4-1 \mathrm{BB}$ costimulatory signals preferentially induce $\mathrm{CD} 8+\mathrm{T}$ cell proliferation and lead to the amplification in vivo of cytotoxic $\mathrm{T}$ cell responses. J Exp Med. (1997) 186:47-55. doi: 10.1084/jem.186.1.47

128. Chu DT, Bac ND, Nguyen KH, Tien NLB, Thanh VV, Nga VT, et al. An update on Anti-CD137 antibodies in immunotherapies for cancer. Int $\mathrm{J} \mathrm{Mol}$ Sci. (2019) 20:1822. doi: 10.3390/ijms20081822

129. Waickman AT, Alme A, Senaldi L, Zarek PE, Horton M, Powell JD. Enhancement of tumor immunotherapy by deletion of the A2A adenosine receptor. Cancer Immunol Immunother. (2012) 61:917-26. doi: 10.1007/s00262-011-1155-7

130. Beavis PA, Henderson MA, Giuffrida L, Mills JK, Sek K, Cross RS, et al. Targeting the adenosine $2 \mathrm{~A}$ receptor enhances chimeric antigen receptor $\mathrm{T}$ cell efficacy. J Clin Invest. (2017) 127:929-41. doi: 10.1172/JCI89455

131. Sitarz R, Skierucha M, Mielko J, Offerhaus GJA, Maciejewski R, Polkowski WP. Gastric cancer: epidemiology, prevention, classification, and treatment. Cancer Manag Res. (2018) 10:239-48. doi: 10.2147/CMAR.S149619

132. Woo Y, Goldner B, Son T, Song K, Noh SH, Fong Y, et al. Western validation of a novel gastric cancer prognosis prediction model in US gastric cancer patients. J Am Coll Surg. (2018) 226:252-8. doi: 10.1016/j.jamcollsurg.2017.12.016

133. Jim MA, Pinheiro PS, Carreira H, Espey DK, Wiggins CL, Weir HK. Stomach cancer survival in the United States by race and stage (20012009): findings from the CONCORD-2 study. Cancer. (2017) 123(Suppl 24):4994-5013. doi: $10.1002 /$ cncr.30881

134. Dolcetti R, De Re V, Canzonieri V. Immunotherapy for gastric cancer: time for a personalized approach? Int J Mol Sci. (2018) 19. doi: 10.3390/ijms 19061602

135. Hu S, Meng F, Yin X, Cao C, Zhang G. NT5E is associated with unfavorable prognosis and regulates cell proliferation and motility in gastric cancer. Biosci Rep. (2019) 39. doi: 10.1042/BSR20190101

136. Jiang T, Xu X, Qiao M, Li X, Zhao C, Zhou F, et al. Comprehensive evaluation of NT5E/CD73 expression and its prognostic significance in distinct types of cancers. BMC Cancer. (2018) 18:267. doi: 10.1186/s12885-018-4073-7

137. Wong KK, Tsang YT, Deavers MT, Mok SC, Zu Z, Sun C, et al. BRAF mutation is rare in advanced-stage low-grade ovarian serous carcinomas. Am J Pathol. (2010) 177:1611-7. doi: 10.2353/ajpath.2010.100212

138. Rajagopalan H, Bardelli A, Lengauer C, Kinzler KW, Vogelstein B, Velculescu VE. Tumorigenesis: RAF/RAS oncogenes and mismatch-repair status. Nature. (2002) 418:934. doi: 10.1038/418934a 
139. Davies H, Bignell GR, Cox C, Stephens P, Edkins S, Clegg S, et al. Mutations of the BRAF gene in human cancer. Nature. (2002) 417:94954. doi: 10.1038 /nature00766

140. Tran B, Kopetz S, Tie J, Gibbs P, Jiang ZQ, Lieu CH, et al. Impact of BRAF mutation and microsatellite instability on the pattern of metastatic spread and prognosis in metastatic colorectal cancer. Cancer. (2011) 117:462332. doi: $10.1002 / \mathrm{cncr} .26086$

141. Wang H, Lee S, Nigro CL, Lattanzio L, Merlano M, Monteverde M, et al. NT5E (CD73) is epigenetically regulated in malignant melanoma and associated with metastatic site specificity. Br J Cancer. (2012) 106:144652. doi: 10.1038/bjc.2012.95

142. Lo Nigro C, Monteverde M, Lee S, Lattanzio L, Vivenza D, Comino A, et al. NT5E CpG island methylation is a favourable breast cancer biomarker. $\mathrm{Br} \mathrm{J}$ Cancer. (2012) 107:75-83. doi: 10.1038/bjc.2012.212

143. Wu C, Zhu Y, Jiang J, Zhao J, Zhang XG, Xu N. Immunohistochemical localization of programmed death-1 ligand-1 (PD-L1) in gastric carcinoma and its clinical significance. Acta Histochem. (2006) 108:19-24. doi: 10.1016/j.acthis.2006.01.003

144. Boison D, Yegutkin GG. Adenosine metabolism: emerging concepts for cancer therapy. Cancer Cell. (2019) 36:58296. doi: 10.1016/j.ccell.2019.10.007

145. Hogan KA, Chini CCS, Chini EN. The multi-faceted ecto-enzyme CD38: roles in immunomodulation, cancer, aging,, and metabolic diseases. Front Immunol. (2019) 10:1187. doi: 10.3389/fimmu.2019.01187

146. Vigano S, Alatzoglou D, Irving M, Menetrier-Caux C, Caux C, Romero $\mathrm{P}$, et al. Targeting adenosine in cancer immunotherapy to enhance T-cell function. Front Immunol. (2019) 10:925. doi: 10.3389/fimmu.2019.00925

147. Parkin DM. The global health burden of infection-associated cancers in the year 2002. Int J Cancer. (2006) 118:3030-44. doi: 10.1002/ijc.21731

148. Sepulveda AR. Helicobacter, inflammation, and gastric cancer. Curr Pathobiol Rep. (2013) 1:9-18. doi: 10.1007/s40139-013-0009-8

149. Wu YY, Lin CW, Cheng KS, Lin C, Wang YM, Lin IT, et al. Increased programmed death-ligand-1 expression in human gastric epithelial cells in Helicobacter pylori infection. Clin Exp Immunol. (2010) 161:5519. doi: 10.1111/j.1365-2249.2010.04217.x

150. Beswick EJ, Pinchuk IV, Das S, Powell DW, Reyes VE. Expression of the programmed death ligand $1, \mathrm{~B} 7-\mathrm{H} 1$, on gastric epithelial cells after Helicobacter pylori exposure promotes development of $\mathrm{CD} 4+$ CD25+ FoxP3+ regulatory $\mathrm{T}$ cells. Infect Immun. (2007) 75:433441. doi: 10.1128/IAI.00553-07

151. Alam MS, Kurtz CC, Rowlett RM, Reuter BK, Wiznerowicz E, Das S, et al. CD73 is expressed by human regulatory $\mathrm{T}$ helper cells and suppresses proinflammatory cytokine production, and Helicobacter felis-induced gastritis in mice. J Infect Dis. (2009) 199:494-504. doi: 10.1086/596205

152. Wang J, Yao $\mathrm{Y}$, Chen $\mathrm{X}$, Wu J, Gu T, Tang $\mathrm{X}$. Host derived exosomes-pathogens interactions: potential functions of exosomes in pathogen infection. Biomed Pharmacother. (2018) 108:14519. doi: 10.1016/j.biopha.2018.09.174

153. Nguyen PH, Giraud J, Chambonnier L, Dubus P, Wittkop L, Belleannee G, et al. Characterization of biomarkers of tumorigenic, and chemoresistant cancer stem cells in human gastric carcinoma. Clin Cancer Res. (2017) 23:1586-97. doi: 10.1158/1078-0432.CCR-15-2157

154. Saitoh M, Nagai K, Nakagawa K, Yamamura T, Yamamoto S, Nishizaki T. Adenosine induces apoptosis in the human gastric cancer cells via an intrinsic pathway relevant to activation of AMP-activated protein kinase. Biochem Pharmacol. (2004) 67:2005-11. doi: 10.1016/j.bcp.2004. 01.020

155. Tsuchiya A, Nishizaki T. Anticancer effect of adenosine on gastric cancer via diverse signaling pathways. World J Gastroenterol. (2015) 21:109315. doi: 10.3748/wjg.v21.i39.10931

156. Griffiths M, Beaumont N, Yao SY, Sundaram M, Boumah CE, Davies A, et al. Cloning of a human nucleoside transporter implicated in the cellular uptake of adenosine and chemotherapeutic drugs. Nat Med. (1997) 3:8993. doi: 10.1038/nm0197-89

157. Griffiths M, Yao SY, Abidi F, Phillips SE, Cass CE, Young JD, et al. Molecular cloning and characterization of a nitrobenzylthioinosine-insensitive (ei) equilibrative nucleoside transporter from human placenta. Biochem J. (1997) 328 (Pt 3):739-43. doi: 10.1042/bj3280739
158. Ali H, Cunha-Melo JR, Saul WF, Beaven MA. Activation of phospholipase C via adenosine receptors provides synergistic signals for secretion in antigenstimulated RBL-2H3 cells. Evidence for a novel adenosine receptor. J Biol Chem. (1990) 265:745-53.

159. Zhou QY, Li C, Olah ME, Johnson RA, Stiles GL, Civelli O. Molecular cloning and characterization of an adenosine receptor: the $\mathrm{A} 3$ adenosine receptor. Proc Natl Acad Sci USA. (1992) 89:7432-6. doi: 10.1073/pnas.89.16.7432

160. Varani K, Merighi S, Gessi S, Klotz KN, Leung E, Baraldi PG, et al. [(3)H]MRE 3008F20: a novel antagonist radioligand for the pharmacological and biochemical characterization of human A(3) adenosine receptors. Mol Pharmacol. (2000) 57:968-75.

161. Merighi S, Benini A, Mirandola P, Gessi S, Varani K, Leung E, et al. A3 adenosine receptors modulate hypoxia-inducible factor-1alpha expression in human A375 melanoma cells. Neoplasia. (2005) 7:894903. doi: $10.1593 /$ neo.05334

162. Shi L, Wu Z, Miao J, Du S, Ai S, Xu E, et al. Adenosine interaction with adenosine receptor $\mathrm{A} 2 \mathrm{a}$ promotes gastric cancer metastasis by enhancing PI3K-AKT-mTOR signaling. Mol Biol Cell. (2019) 30:252734. doi: 10.1091/mbc.E19-03-0136

163. Llovet JM, Zucman-Rossi J, Pikarsky E, Sangro B, Schwartz M, Sherman M, et al. Hepatocellular carcinoma. Nat Rev Dis Primers. (2016) 2:16018. doi: $10.1038 / \mathrm{nrdp} .2016 .18$

164. Nzeako UC, Goodman ZD, Ishak KG. Hepatocellular carcinoma in cirrhotic and noncirrhotic livers. A clinico-histopathologic study of 804 North American patients. Am J Clin Pathol. (1996) 105:6575. doi: 10.1093/ajcp/105.1.65

165. Mullin AS, Guo H, McCoy AB. Viewpoint: new physical insights from kinetics studies. J Phys Chem A. (2019) 123:3057. doi: 10.1021/acs.jpca.9b02535

166. Llovet JM, Ricci S, Mazzaferro V, Hilgard P, Gane E, Blanc JF, et al. Sorafenib in advanced hepatocellular carcinoma. $N$ Engl J Med. (2008) 359:378-90. doi: 10.1056/NEJMoa0708857

167. Johnston MP, Khakoo SI. Immunotherapy for hepatocellular carcinoma: current and future. World J Gastroenterol. (2019) 25:2977-89. doi: 10.3748/wjg.v25.i24.2977

168. Snider NT, Altshuler PJ, Wan S, Welling TH, Cavalcoli J, Omary MB. Alternative splicing of human NT5E in cirrhosis and hepatocellular carcinoma produces a negative regulator of ecto-5'-nucleotidase (CD73). Mol Biol Cell. (2014) 25:4024-33. doi: 10.1091/mbc.e1406-1167

169. Alcedo KP, Guerrero A, Basrur V, Fu D, Richardson ML, McLane JS, et al. Tumor-selective altered glycosylation, and functional attenuation of CD73 in human hepatocellular carcinoma. Hepatol Commun. (2019) 3:140014. doi: $10.1002 /$ hep 4.1410

170. Ma XL, Shen MN, Hu B, Wang BL, Yang WJ, Lv LH, et al. CD73 promotes hepatocellular carcinoma progression and metastasis via activating PI3K/AKT signaling by inducing Rap1-mediated membrane localization of P110beta and predicts poor prognosis. J Hematol Oncol. (2019) 12:37. doi: 10.1186/s13045-019-0724-7

171. Shrestha R, Prithviraj P, Anaka M, Bridle KR, Crawford DHG, Dhungel B, et al. Monitoring immune checkpoint regulators as predictive biomarkers in hepatocellular carcinoma. Front Oncol. (2018) 8:269. doi: $10.3389 /$ fonc. 2018.00269

172. Sciarra A, Monteiro I, Menetrier-Caux C, Caux C, Gilbert B, Halkic $\mathrm{N}$, et al. de Leval: CD73 expression in normal and pathological human hepatobiliopancreatic tissues. Cancer Immunol Immunother. (2019) 68:46778. doi: $10.1007 / \mathrm{s} 00262-018-2290-1$

173. St Hilaire C, Ziegler SG, Markello TC, Brusco A, Groden C, Gill F, et al. NT5E mutations and arterial calcifications. N Engl J Med. (2011) 364:43242. doi: 10.1056/NEJMoa0912923

174. Joolharzadeh P, St Hilaire C. CD73 (cluster of differentiation 73) and the differences between mice, and humans. Arterioscler Thromb Vasc Biol. (2019) 39:339-48. doi: 10.1161/ATVBAHA.118. 311579

175. Bowser JL, Blackburn MR, Shipley GL, Molina JG, Dunner K Jr, Broaddus RR. Loss of CD73-mediated actin polymerization promotes endometrial tumor progression. J Clin Invest. (2016) 126:220-38. doi: 10.1172/ JCI79380 
176. Kruger KH, Thompson LF, Kaufmann M, Moller P. Expression of ecto-5'nucleotidase (CD73) in normal mammary gland and in breast carcinoma. $\mathrm{Br}$ J Cancer. (1991) 63:114-8. doi: 10.1038/bjc.1991.23

177. Gordon LA, Mulligan KT, Maxwell-Jones H, Adams M, Walker RA, Jones JL. Breast cell invasive potential relates to the myoepithelial phenotype. Int J Cancer. (2003) 106:8-16. doi: 10.1002/ijc.11172

178. Sorlie T, Perou CM, Tibshirani R, Aas T, Geisler S, Johnsen H, et al. Borresen-Dale: Gene expression patterns of breast carcinomas distinguish tumor subclasses with clinical implications. Proc Natl Acad Sci USA. (2001) 98:10869-74. doi: 10.1073/pnas.1913 67098

179. Minor M, Alcedo KP, Battaglia RA, Snider NT. Cell type- and tissue-specific functions of ecto-5'-nucleotidase (CD73). Am J Physiol Cell Physiol. (2019) 317:C1079-92. doi: 10.1152/ajpcell.00285.2019

180. Bowser JL, Broaddus RR. CD73s protection of epithelial integrity: thinking beyond the barrier. Tissue Barriers. (2016) 4:e1224963. doi: 10.1080/21688370.2016.1224963

181. Rackley RR, Lewis TJ, Preston EM, Delmoro CM, Bradley EL Jr, Resnick MI, et al. 5'-nucleotidase activity in prostatic carcinoma and benign prostatic hyperplasia. Cancer Res. (1989) 49:3702-7.

182. Wettstein MS, Buser L, Hermanns T, Roudnicky F, Eberli D, Baumeister P, et al. CD73 predicts favorable prognosis in patients with nonmuscle-invasive urothelial bladder cancer. Dis Markers. (2015) 2015:785461. doi: 10.1155/2015/785461

183. Sun X, Han L, Seth P, Bian S, Li L, Csizmadia E, et al. Disordered purinergic signaling and abnormal cellular metabolism are associated with development of liver cancer in Cd39/ENTPD1 null mice. Hepatology. (2013) 57:20516. doi: 10.1002/hep.25989

184. Xiang HJ, Liu ZC, Wang DS, Chen Y, Yang YL, Dou KF. Adenosine $\mathrm{A}(2 \mathrm{~b})$ receptor is highly expressed in human hepatocellular carcinoma. Hepatol Res. (2006) 36:56-60. doi: 10.1016/j.hepres.2006. 06.008

185. Lan J, Lu H, Samanta D, Salman S, Lu Y, Semenza GL. Hypoxia-inducible factor 1-dependent expression of adenosine receptor $2 \mathrm{~B}$ promotes breast cancer stem cell enrichment. Proc Natl Acad Sci USA. (2018) 115:E96408. doi: 10.1073/pnas.1809695115

186. Panjehpour M, Castro M, Klotz KN. Human breast cancer cell line MDA-MB-231 expresses endogenous A2B adenosine receptors mediating a Ca2+ signal. Br J Pharmacol. (2005) 145:211-8. doi: 10.1038/sj.bjp. 0706180

187. Ma DF, Kondo T, Nakazawa T, Niu DF, Mochizuki K, Kawasaki $\mathrm{T}$, et al. Hypoxia-inducible adenosine A2B receptor modulates proliferation of colon carcinoma cells. Hum Pathol. (2010) 41:1550-7. doi: 10.1016/j.humpath.2010.04.008

188. Vecchio EA, Tan CY, Gregory KJ, Christopoulos A, White PJ, May LT. Ligand-independent adenosine $\mathrm{A} 2 \mathrm{~B}$ receptor constitutive activity as a promoter of prostate cancer cell proliferation. J Pharmacol Exp Ther. (2016) 357:36-44. doi: 10.1124/jpet.115.230003

189. Bar-Yehuda S, Stemmer SM, Madi L, Castel D, Ochaion A, Cohen S, et al. The A3 adenosine receptor agonist CF102 induces apoptosis of hepatocellular carcinoma via de-regulation of the Wnt, and NF-kappaB signal transduction pathways. Int J Oncol. (2008) 33:287-95.

190. Stemmer SM, Manojlovic NS, Marinca MV, Petrov P, Cherciu N, Ganea $\mathrm{D}$, et al. A phase II, randomized, double-blind, placebo-controlled trial evaluating efficacy and safety of namodenoson (CF102), an A3 adenosine receptor agonist (A3AR), as a second-line treatment in patients with Child-Pugh B (CPB) advanced hepatocellular carcinoma (HCC). J Clin Oncol. (2019) 37(15_suppl):2503. doi: 10.1200/JCO.2019.37.15_suppl. 2503

191. Adel N. Current treatment landscape and emerging therapies for pancreatic cancer. Am J Manag Care. (2019) 25(1 Suppl):S3-S10.

192. McGuigan A, Kelly P, Turkington RC, Jones C, Coleman HG, McCain RS. Pancreatic cancer: a review of clinical diagnosis, epidemiology, treatment and outcomes. World J Gastroenterol. (2018) 24:4846-61. doi: 10.3748/wjg.v24.i43.4846

193. Rawla P, Sunkara T, Gaduputi V. Epidemiology of pancreatic cancer: global trends, etiology, and risk factors. World J Oncol. (2019) 10:1027. doi: $10.14740 /$ wjon 1166
194. Brahmer JR, Tykodi SS, Chow LQ, Hwu WJ, Topalian SL, Hwu P, et al. Safety and activity of anti-PD-L1 antibody in patients with advanced cancer. $\mathrm{N} \mathrm{Engl}$ J Med. (2012) 366:2455-65. doi: 10.1056/NEJMoa1200694

195. Royal RE, Levy C, Turner K, Mathur A, Hughes M, Kammula US, et al. Phase 2 trial of single agent Ipilimumab (anti-CTLA-4) for locally advanced or metastatic pancreatic adenocarcinoma. J Immunother. (2010) 33:82833. doi: 10.1097/CJI.0b013e3181eec14c

196. O’Reilly EM, Oh DY, Dhani N, Renouf DJ, Lee MA, Sun W, et al. Durvalumab with or without tremelimumab for patients with metastatic pancreatic ductal adenocarcinoma: a phase 2 randomized clinical trial. JAMA Oncol. (2019) 5:1431-8. doi: 10.1001/jamaoncol.2019.1588

197. Nomi T, Sho M, Akahori T, Hamada K, Kubo A, Kanehiro H, et al. Clinical significance and therapeutic potential of the programmed death1 ligand/programmed death-1 pathway in human pancreatic cancer. Clin Cancer Res. (2007) 13:2151-7. doi: 10.1158/1078-0432.CCR-06-2746

198. Yamaki S, Yanagimoto H, Tsuta K, Ryota H, Kon M. PD-L1 expression in pancreatic ductal adenocarcinoma is a poor prognostic factor in patients with high CD8(+) tumor-infiltrating lymphocytes: highly sensitive detection using phosphor-integrated dot staining. Int J Clin Oncol. (2017) 22:72633. doi: 10.1007/s10147-017-1112-3

199. Zhuan-Sun Y, Huang F, Feng M, Zhao X, Chen W, Zhu Z, et al. Prognostic value of PD-L1 overexpression for pancreatic cancer: evidence from a metaanalysis. Onco Targets Ther. (2017) 10:5005-12. doi: 10.2147/OTT.S146383

200. Johnson BA 3rd, Yarchoan M, Lee V, Laheru DA, Jaffee EM. Strategies for increasing pancreatic tumor immunogenicity. Clin Cancer Res. (2017) 23:1656-69. doi: 10.1158/1078-0432.CCR-16-2318

201. Gunderson AJ, Kaneda MM, Tsujikawa T, Nguyen AV, Affara NI, Ruffell B, et al. Bruton tyrosine kinase-dependent immune cell cross-talk drives pancreas cancer. Cancer Discov. (2016) 6:270-85. doi: 10.1158/2159-8290.CD-15-0827

202. Masso-Valles D, Jauset T, Serrano E, Sodir NM, Pedersen K, Affara $\mathrm{NI}$, et al. Ibrutinib exerts potent antifibrotic and antitumor activities in mouse models of pancreatic adenocarcinoma. Cancer Res. (2015) 75:167581. doi: 10.1158/0008-5472.CAN-14-2852

203. Thomas D, Radhakrishnan P. Tumor-stromal crosstalk in pancreatic cancer and tissue fibrosis. Mol Cancer. (2019) 18:14. doi: 10.1186/s12943-018-0927-5

204. Tempero MA, Coussens LM, Fong L, Manges R, Singh P, Cole YL, et al. A randomized, multicenter, double-blind, placebo-controlled study of the Bruton tyrosine kinase inhibitor, ibrutinib, versus placebo in combination with nab-paclitaxel and gemcitabine in the first-line treatment of patients with metastatic pancreatic adenocarcinoma (RESOLVE). J Clin Oncol. (2016) 34(4_suppl):tps483. doi: 10.1200/jco.2016.34.4_suppl.tps483

205. Jakel C, Bergmann F, Toth R, Assenov Y, van der Duin D, Strobel O, et al. Genome-wide genetic and epigenetic analyses of pancreatic acinar cell carcinomas reveal aberrations in genome stability. Nat Commun. (2017) 8:1323. doi: 10.1038/s41467-017-01118-x

206. Waters AM, Der CJ. KRAS: the critical driver, and therapeutic target for pancreatic cancer. Cold Spring Harb Perspect Med. (2018) 8. doi: 10.1101/cshperspect.a031435

207. Udyavar AR, DiRenzo D, Piovesan D, Ashok D, Anderson AE, Young SW, et al. Altered pan-Ras pathway and activating mutations in EGFR result in elevated CD73 in multiple cancers. In: AACR abstract \#2526, Arcus Biosciences Poster. (2019). Available online at: https://www.arcusbio.com/ static/media/Adenosine_PanRAS_EGFR-Relationship-Akshata-AACR2019--1.7b11622c.pdf

208. Oliveira-Cunha M, Newman WG, Siriwardena AK. Epidermal growth factor receptor in pancreatic cancer. Cancers. (2011) 3:1513-26. doi: 10.3390/cancers3021513

209. Zhi X, Wang Y, Yu J, Yu J, Zhang L, Yin L, et al. Potential prognostic biomarker CD73 regulates epidermal growth factor receptor expression in human breast cancer. IUBMB Life. (2012) 64:911-20. doi: 10.1002/iub.1086

210. Hiraoka N, Onozato K, Kosuge T, Hirohashi S. Prevalence of FOXP3+ regulatory $\mathrm{T}$ cells increases during the progression of pancreatic ductal adenocarcinoma and its premalignant lesions. Clin Cancer Res. (2006) 12:5423-34. doi: 10.1158/1078-0432.CCR-06-0369

211. Schuler PJ, Saze Z, Hong CS, Muller L, Gillespie DG, Cheng D, et al. Human $\mathrm{CD} 4+\mathrm{CD} 39+$ regulatory $\mathrm{T}$ cells produce adenosine upon co-expression of 
surface CD73 or contact with CD73+ exosomes or CD73+ cells. Clin Exp Immunol. (2014) 177:531-43. doi: 10.1111/cei.12354

212. Gorzalczany Y, Merimsky O, Sagi-Eisenberg R. Mast cells are directly activated by cancer cell-derived extracellular vesicles by a CD73-, and adenosine-dependent mechanism. Transl Oncol. (2019) 12:154956. doi: 10.1016/j.tranon.2019.08.005

213. Gorzalczany Y, Akiva E, Klein O, Merimsky O, Sagi-Eisenberg R. Mast cells are directly activated by contact with cancer cells by a mechanism involving autocrine formation of adenosine and autocrine/paracrine signaling of the adenosine A3 receptor. Cancer Lett. (2017) 397:2332. doi: 10.1016/j.canlet.2017.03.026

214. Barilla RM, Diskin B, Caso RC, Lee KB, Mohan N, Buttar C, et al. Specialized dendritic cells induce tumor-promoting IL-10(+)IL-17(+) FoxP3(neg) regulatory CD4(+) T cells in pancreatic carcinoma. Nat Commun. (2019) 10:1424. doi: 10.1038/s41467-019-09416-2

215. Yao JC, Eisner MP, Leary C, Dagohoy C, Phan A, Rashid A, et al. Populationbased study of islet cell carcinoma. Ann Surg Oncol. (2007) 14:3492500. doi: 10.1245/s10434-007-9566-6

216. Yao JC, Hassan M, Phan A, Dagohoy C, Leary C, Mares JE, et al. One hundred years after "carcinoid": epidemiology of and prognostic factors for neuroendocrine tumors in 35,825 cases in the United States. J Clin Oncol. (2008) 26:3063-72. doi: 10.1200/JCO.2007.15.4377

217. Ono K, Shiozawa E, Ohike N, Fujii T, Shibata H, Kitajima T, et al. Immunohistochemical $\mathrm{CD} 73$ expression status in gastrointestinal neuroendocrine neoplasms: a retrospective study of 136 patients. Oncol Lett. (2018) 15:2123-30. doi: 10.3892/ol.2017.7569

218. Filippini D, Agosto S, Delfino P, Simbolo M, Piro G, Rusev $\mathrm{B}$, et al. Immunoevolution of mouse pancreatic organoid isografts from preinvasive to metastatic disease. Sci Rep. (2019) 9:12286. doi: 10.1038/s41598-019-48663-7

219. Yang D, Zhang Q, Ma Y, Che Z, Zhang W, Wu M, et al. Augmenting the therapeutic efficacy of adenosine against pancreatic cancer by switching the Akt/p21-dependent senescence to apoptosis. EBioMedicine. (2019) 47:11427. doi: $10.1016 /$ j.ebiom.2019.08.068

220. Kunzli BM, Bernlochner MI, Rath S, Kaser S, Csizmadia E, Enjyoji $\mathrm{K}$, et al. Impact of $\mathrm{CD} 39$ and purinergic signalling on the growth and metastasis of colorectal cancer. Purinergic Signal. (2011) 7:23141. doi: 10.1007/s11302-011-9228-9

221. Cronin KA, Lake AJ, Scott S, Sherman RL, Noone AM, Howlader N, et al. Annual report to the nation on the status of cancer, part I: national cancer statistics. Cancer. (2018) 124:2785-800. doi: 10.1002/cncr.31551

222. Arnold M, Sierra MS, Laversanne M, Soerjomataram I, Jemal A, Bray F. Global patterns and trends in colorectal cancer incidence and mortality. Gut. (2017) 66:683-91. doi: 10.1136/gutjnl-2015-310912

223. Johnson CM, Wei C, Ensor JE, Smolenski DJ, Amos CI, Levin B, et al. Meta-analyses of colorectal cancer risk factors. Cancer Causes Control. (2013) 24:1207-22. doi: 10.1007/s10552-013-0201-5

224. Dekker E, Tanis PJ, Vleugels JLA, Kasi PM, Wallace MB. Colorectal cancer. Lancet. (2019) 394:1467-80. doi: 10.1016/S0140-6736(19) 32319-0

225. Crooke H, Kobayashi M, Mitchell B, Nwokeji E, Laurie M, Kamble $\mathrm{S}$, et al. Estimating 1- and 5-year relative survival trends in colorectal cancer (CRC) in the United States: 2004 to 2014. J Clin Oncol. (2018) 36(4_suppl):587. doi: 10.1200/JCO.2018.36.4_suppl.587

226. Kalyan A, Kircher S, Shah H, Mulcahy M, Benson A. Updates on immunotherapy for colorectal cancer. J Gastrointest Oncol. (2018) 9:1609. doi: 10.21037 /jgo.2018.01.17

227. Camici M, Tozzi MG, Allegrini S, Del Corso A, Sanfilippo O, Daidone MG, et al. Purine salvage enzyme activities in normal and neoplastic human tissues. Cancer Biochem Biophys. (1990) 11:201-9.

228. Eroglu A, Canbolat O, Demirci S, Kocaoglu H, Eryavuz Y, Akgul $\mathrm{H}$. Activities of adenosine deaminase and 5'-nucleotidase in cancerous and noncancerous human colorectal tissues. Med Oncol. (2000) 17:31924. doi: $10.1007 / \mathrm{BF} 02782198$

229. Zhang B, Song B, Wang X, Chang XS, Pang T, Zhang X, et al. The expression and clinical significance of $\mathrm{CD} 73$ molecule in human rectal adenocarcinoma. Tumour Biol. (2015) 36:5459-66. doi: 10.1007/s13277-015$3212-\mathrm{x}$
230. Koivisto MK, Tervahartiala M, Kenessey I, Jalkanen S, Bostrom PJ, Salmi M. Cell-type-specific CD73 expression is an independent prognostic factor in bladder cancer. Carcinogenesis. (2019) 40:84-92. doi: 10.1093/carcin/bgy154

231. McGranahan N, Swanton C. Clonal heterogeneity, and tumor evolution: past, present, and the future. Cell. (2017) 168:61328. doi: 10.1016/j.cell.2017.01.018

232. Blank A, Roberts DE II, Dawson H, Zlobec I, Lugli A. Tumor heterogeneity in primary colorectal cancer, and corresponding metastases. does the apple fall far from the tree? Front Med. (2018) 5:234. doi: 10.3389/fmed.2018.00234

233. Guinney J, Dienstmann R, Wang X, de Reynies A, Schlicker A, Soneson C, et al. The consensus molecular subtypes of colorectal cancer. Nat Med. (2015) 21:1350-6. doi: 10.1038/nm.3967

234. Cushman SM, Jiang C, Hatch AJ, Shterev I, Sibley AB, Niedzwiecki D, et al. Gene expression markers of efficacy and resistance to cetuximab treatment in metastatic colorectal cancer: results from CALGB 80203 (Alliance). Clin Cancer Res. (2015) 21:1078-86. doi: 10.1158/1078-0432.CCR-14-2313

235. Sveen A, Bruun J, Eide PW, Eilertsen IA, Ramirez L, Murumagi A, et al. Colorectal cancer consensus molecular subtypes translated to preclinical models uncover potentially targetable cancer cell dependencies. Clin Cancer Res. (2018) 24:794-806. doi: 10.1158/1078-0432.CCR-17-1234

236. Wu R, Chen Y, Li F, Li W, Zhou H, Yang Y, et al. Effects of CD73 on human colorectal cancer cell growth in vivo and in vitro. Oncol Rep. (2016) 35:1750-6. doi: 10.3892/or.2015.4512

237. Van Cutsem E, Nordlinger B, Cervantes A, Group EGW. Advanced colorectal cancer: ESMO clinical practice guidelines for treatment. Ann Oncol. (2010) 21(Suppl. 5):v93-7. doi: 10.1093/annonc/mdq222

238. Messaoudi N, Henault D, Stephen D, Cousineau I, St-Hilaire, PA, Vandenbroucke-Menu F, et al. Prognostic value of CD73 expression in resected colorectal cancer liver metastasis. J Clin Oncol. (2018) 36:3584. doi: 10.1200/JCO.2018.36.15_suppl.3584

239. Sun $\mathrm{X}, \mathrm{Wu} \mathrm{Y}$, Gao W, Enjyoji K, Csizmadia E, Muller CE, et al. CD39/ENTPD1 expression by CD4+Foxp3+ regulatory T cells promotes hepatic metastatic tumor growth in mice. Gastroenterology. (2010) 139:103040. doi: 10.1053/j.gastro.2010.05.007

240. Jackson SW, Hoshi T, Wu Y, Sun X, Enjyoji K, Cszimadia E, et al. Disordered purinergic signaling inhibits pathological angiogenesis in cd39/Entpd1-null mice. Am J Pathol. (2007) 171:1395-404. doi: 10.2353/ajpath.2007.070190

241. Wu Z, Yang L, Shi L, Song H, Shi P, Yang T, et al. Prognostic impact of adenosine receptor $2(\mathrm{~A} 2 \mathrm{aR})$, and programmed cell death ligand 1 (PD-L1) expression in colorectal cancer. Biomed Res Int. (2019) 2019:8014627. doi: 10.1155/2019/8014627

242. Yu M, Guo G, Huang L, Deng L, Chang CS, Achyut BR, et al. CD73 on cancer-associated fibroblasts enhanced by the A2B-mediated feedforward circuit enforces an immune checkpoint. Nat Commun. (2020) 11:515. doi: $10.1038 / s 41467-019-14060-\mathrm{x}$

243. Gessi S, Cattabriga E, Avitabile A, Gafa R, Lanza G, Cavazzini L, et al. Elevated expression of A3 adenosine receptors in human colorectal cancer is reflected in peripheral blood cells. Clin Cancer Res. (2004) 10:5895901. doi: 10.1158/1078-0432.CCR-1134-03

244. Gessi S, Merighi S, Varani K, Cattabriga E, Benini A, Mirandola P, et al. Adenosine receptors in colon carcinoma tissues and colon tumoral cell lines: focus on the A(3) adenosine subtype. J Cell Physiol. (2007) 211:82636. doi: $10.1002 /$ jcp. 20994

245. Ohana G, Bar-Yehuda S, Arich A, Madi L, Dreznick Z, Rath-Wolfson L, et al. Inhibition of primary colon carcinoma growth and liver metastasis by the A3 adenosine receptor agonist CF101. Br J Cancer. (2003) 89:15528. doi: $10.1038 /$ sj.bjc. 6601315

246. Fishman P, Bar-Yehuda S, Ohana G, Barer F, Ochaion A, Erlanger A, et al. An agonist to the $\mathrm{A} 3$ adenosine receptor inhibits colon carcinoma growth in mice via modulation of GSK-3 beta, and NF-kappa B. Oncogene. (2004) 23:2465-71. doi: 10.1038/sj.onc. 1207355

247. Bar-Yehuda S, Madi L, Silberman D, Gery S, Shkapenuk M, Fishman $\mathrm{P}$. CF101, an agonist to the A3 adenosine receptor, enhances the chemotherapeutic effect of 5 -fluorouracil in a colon carcinoma murine model. Neoplasia. (2005) 7:85-90. doi: 10.1593/neo.04364

248. Merighi S, Benini A, Mirandola P, Gessi S, Varani K, Simioni C, et al. Caffeine inhibits adenosine-induced accumulation of hypoxia-inducible factorlalpha, vascular endothelial growth factor, and interleukin-8 expression 
in hypoxic human colon cancer cells. Mol Pharmacol. (2007) 72:395406. doi: $10.1124 / \mathrm{mol} .106 .032920$

249. Imamura T, Kikuchi H, Herraiz MT, Park DY, Mizukami Y, Mino-Kenduson M, et al. HIF-1alpha, and HIF-2alpha have divergent roles in colon cancer. Int J Cancer. (2009) 124:763-71. doi: 10.1002/ijc.24032

250. Xue X, Ramakrishnan SK, Shah YM. Activation of HIF-1alpha does not increase intestinal tumorigenesis. Am J Physiol Gastrointest Liver Physiol. (2014) 307:G187-95. doi: 10.1152/ajpgi.00112.2014

251. Siu LL, Burris H, Le DT, Hollebecque A, Steeghs N, Delord, JP, et al. Abstract CT180: preliminary phase 1 profile of BMS-986179, an anti-CD73 antibody, in combination with nivolumab in patients with advanced solid tumors. Cancer Res. (2018) 78. doi: 10.1158/1538-7445.AM2018-CT180. Available online at: https://cancerres.aacrjournals.org/content/78/13_Supplement/ CT180

252. Powderly JD, de Souza PL, Gutierrez R, Horvath L, Seitz L, Ashok $\mathrm{D}$, et al. AB928, a novel dual adenosine receptor antagonist, combined with chemotherapy or AB122 (anti-PD-1) in patients (pts) with advanced tumors: Preliminary results from ongoing phase I studies. J Clin Oncol. (2019) doi: 10.1200/JCO.2019.37.15_suppl.2604

253. Garrido F, Cabrera T, Aptsiauri N. "Hard" and "soft" lesions underlying the HLA class I alterations in cancer cells: implications for immunotherapy. Int J Cancer. (2010) 127:249-56. doi: 10.1002/ijc.25270

254. Lampen MH, van Hall T. Strategies to counteract MHC-I defects in tumors. Curr Opin Immunol. (2011) 23:293-8. doi: 10.1016/j.coi.2010.12.005

255. Laheru D, Jaffee EM. Immunotherapy for pancreatic cancer - science driving clinical progress. Nat Rev Cancer. (2005) 5:459-67. doi: 10.1038/nrc1630

256. Rezvani $\mathrm{K}$, de Lavallade $\mathrm{H}$. Vaccination strategies in lymphomas and leukaemias: recent progress. Drugs. (2011) 71:165974. doi: 10.2165/11593270-000000000-00000

257. Blankenstein T, Coulie PG, Gilboa E, Jaffee EM. The determinants of tumour immunogenicity. Nat Rev Cancer. (2012) 12:307-13. doi: 10.1038/nrc3246

258. Pradeu T, Carosella ED. On the definition of a criterion of immunogenicity. Proc Natl Acad Sci USA. (2006) 103:17858-61. doi: 10.1073/pnas.0608683103
259. Gelfo V, Rodia MT, Pucci M, Dall'Ora M, Santi S, Solmi R, et al. A module of inflammatory cytokines defines resistance of colorectal cancer to EGFR inhibitors. Oncotarget. (2016) 7:72167-83. doi: 10.18632/oncotarget. 12354

260. Cheng Y, Tian H. Current development status of MEK inhibitors. Molecules. (2017) 22:1551. doi: 10.3390/molecules22101551

261. Eng C, Kim TW, Bendell J, Argiles G, Tebbutt NC, Di Bartolomeo M, et al. Atezolizumab with or without cobimetinib versus regorafenib in previously treated metastatic colorectal cancer (IMblaze370): a multicentre, open-label, phase 3, randomised, controlled trial. Lancet Oncol. (2019) 20:849-61. doi: 10.1016/S1470-2045(19)30027-0

262. Canon J, Rex K, Saiki AY, Mohr C, Cooke K, Bagal D, et al. The clinical KRAS(G12C) inhibitor AMG 510 drives anti-tumour immunity. Nature. (2019) 575:217-23. doi: 10.1038/s41586-019-1694-1

263. Leone RD, Horton MR, Powell JD. Something in the air: hyperoxic conditioning of the tumor microenvironment for enhanced immunotherapy. Cancer Cell. (2015) 27:435-6. doi: 10.1016/j.ccell.2015.03.014

264. Zangl Q, Martignoni A, Jackson SH, Ohta A, Klaunberg B, Kaufmann I, et al. Postoperative hyperoxia (60\%) worsens hepatic injury in mice. Anesthesiology. (2014) 121:1217-25. doi: 10.1097/ALN.00000000000 00447

Conflict of Interest: The authors declare that the research was conducted in the absence of any commercial or financial relationships that could be construed as a potential conflict of interest.

Copyright $(2020$ Harvey, Phan, Villarreal and Bowser. This is an open-access article distributed under the terms of the Creative Commons Attribution License (CC BY). The use, distribution or reproduction in other forums is permitted, provided the original author(s) and the copyright owner(s) are credited and that the original publication in this journal is cited, in accordance with accepted academic practice. No use, distribution or reproduction is permitted which does not comply with these terms. 